\title{
Non-GAAP Earnings and the Earnings Quality Trade-off
}

\author{
Andrea Ribeiro \\ NSW Treasury \\ Yaowen Shan \\ UTS Business School \\ University of Technology Sydney \\ Stephen Taylor* \\ UTS Business School \\ University of Technology Sydney
}

October 2018

JEL Classification: J33, M41

Keywords: Non-GAAP disclosures; Earnings quality

Financial support for this research was provided by the Centre for International Finance and Regulation, the Australian Research Council and the University of Technology Sydney. We appreciate the helpful comments of Jere Francis, Christo Karuna (the UTS Summer Conference discussant), Andrew Jackson (the IASB Research Forum discussant), an anonymous reviewer, attendees at the 2016 UTS Accounting Summer Conference, the 2018 Abacus/IASB Research Forum and workshop participants at the following universities: Adelaide, Monash and Queensland. We acknowledge the research assistance of Zhuoan Feng and Alex Tong, and the database management support of David Simmons and SIRCA.

* Corresponding author

Stephen Taylor

UTS Business School

University of Technology Sydney

PO Box 123 Broadway

NSW 2007 Australia

Stephen.Taylor@uts.edu.au 


\title{
Non-GAAP Earnings and the Earnings Quality Trade-off
}

\begin{abstract}
Using a large sample of earnings press releases by Australian firms, we compare multiple attributes of non-GAAP earnings measures with their closest GAAP equivalent. We find that, on average, non-GAAP earnings are more persistent, smoother, more value-relevant, and have higher predictive power than their closest GAAP equivalent. However, the same set of non-GAAP earnings disclosures are also less conservative and less timely than their closest GAAP equivalent. The results are consistent with non-GAAP earnings measures reflecting a reversal of the trade-off between the valuation and stewardship roles of accounting inherent in accounting standards and the way they are applied. We also find that differences in several of these attributes between GAAP and non-GAAP earnings are more evident in larger firms, firms with lower market-to-book ratios, firms with a higher proportion of independent directors and firms that report profits rather than losses. Our evidence is consistent with the argument that accounting standards impose significant amounts of conditional conservatism at some cost to the valuation role of accounting information. Non-GAAP earnings measures can therefore be seen as a response to the challenges faced by a single GAAP performance measure in satisfying the competing demands of value relevance and stewardship.
\end{abstract}




\section{Introduction}

External financial reporting is typically argued as having important stewardship and valuation roles (IASB 2018). The stewardship role is typically focussed on assessing managerial performance, while the valuation role is most commonly linked to the identification of future net cash flows. ${ }^{1}$ However, although managerial performance and expected future cash flows are likely positively related to each other, there is also widespread recognition that the stewardship and valuation roles may create competing demands in terms of desirable attributes of external financial reporting (Kothari et al. 2010). For example, it has been argued that conditionally conservative income measures facilitate the role of income as an effective measure of managerial performance, and serves as an important mechanism for minimizing agency costs arising between owners and managers (Watts 2003; Ball and Shivakumar 2005). However, such conservatism has a cost, possibly reducing the usefulness of statutory income measures in forecasting future performance and hence, of facilitating valuation.

Apart from recognising that financial reporting has multiple objectives, the International Accounting Standards Board (IASB) has more recently explicitly acknowledged the difficulties of a single income measure satisfying these potentially competing demands (IASB 2017; 2018b). At the same time, recent years have seen a marked rise in the frequency with which firms prominently report non-GAAP earnings measures, often described using terms such as "underlying profit", "cash profit", "recurring earnings" and the like. ${ }^{2}$ Such terms became popular in the US in

\footnotetext{
${ }^{1}$ Although the IASB removed the stewardship term from the 2010 Conceptual Framework it is explicitly recognized in the 2018 version. However, according to the 2018 Conceptual Framework (IASB, 2018a), the main objective of financial reporting "is to provide financial information about the reporting entity that is useful to existing and potential investors, lenders and other creditors in making decisions about providing resources to the entity" (para. 1.2).

2 There are many terms used to describe non-GAAP definitions of earnings. These include (among other terms) cash earnings, underlying profit, recurring profits, pro-forma earnings and normalized earnings. For the purpose of our discussion, we define all such metrics as non-GAAP earnings. We use the term "street earnings" for alternative performance measures reported by analysts forecast services such as $\mathrm{I} / \mathrm{B} / \mathrm{E} / \mathrm{S}$ and Thomson Datastream. In this paper we typically restrict our focus to past research using actual non-GAAP disclosures, rather than proxy measures such as street earnings.
} 
the late $1990 \mathrm{~s}$, but were then made subject to relatively stricter regulation (Kolev et al. 2008). In contrast, this practice has been relatively unregulated in Australia, with evidence of steady growth in the frequency with which firms voluntarily disclose self-determined measures of financial performance (Coulton et al. 2016).

Following Kothari et al. (2010), we argue that performance measures complying with GAAP primarily reflect the stewardship, or control, role of financial reporting. Although most research focuses on the private (i.e., contracting) demand for conditionally conservative accounting, the calculation of earnings measures complying with Generally Accepted Accounting Principles (GAAP) is a highly regulated process, subject to the application of accounting standards and the influence of auditors. Despite explicit recognition by standard setters of the "value relevance" role of financial reporting (e.g., IASB 2018), there is evidence that conditionally conservative measurement practices are inherent in accounting standards (Barker and McGeachin 2015). ${ }^{3}$ Moreover, there are strong incentives for publicly traded companies and their auditors to apply GAAP in a conservative manner (Ball and Shivakumar 2005). ${ }^{4}$ However, conditionally conservative accounting may result in performance measures which are relatively less useful for valuation purposes than otherwise, and there has been an on-going debate about the desirability of conservatism as an attribute of accounting (Cooper 2015).

We characterize the supply of non-GAAP earnings measures as a response to economic demand for information that is not satisfied solely by GAAP earnings. Non-GAAP earnings measures differ from other forms of voluntary disclosure in that non-GAAP earnings represent an alternative, though managerially determined,

\footnotetext{
${ }^{3}$ Barker and McGeachin (2015) document the actual requirements of IFRS that lead to conservative accounting in practice. They distinguish between unconditional conservatism created by recognition rules, and conditional conservatism, which reflects measurement rules. To the extent accounting standards are unconditionally conservative, conditional conservatism will not be evident.

${ }^{4}$ Ball and Shivakumar (2005) suggest that conditional conservatism is embedded in GAAP, via rules requiring lower of cost or market value, asset impairment rules, restructuring charges and the requirement to recognize certain forms of contingent liabilities (to name a few). Ruddock et al. (2006) argue that auditing is asymmetric, with a focus on detecting overstatement of results. Hence, the audit process also adds to the degree to which GAAP is conditionally conservative.
} 
measure of a firm's financial performance. Most other voluntary disclosures are directed at providing supplementary information to assist in interpreting GAAP-based financial performance measures (e.g., an airline providing information on passenger seat-miles). Non-GAAP earnings thus reflect an "undoing" of GAAP, rather than a "clarification".

We therefore examine the extent to which voluntarily disclosed non-GAAP earnings measures demonstrate attributes more consistent with meeting a demand for value-relevant information than a traditional stewardship role. We do so via a comprehensive comparison of non-GAAP earnings attributes with their closest GAAP equivalent. The attributes we examine are earnings persistence, predictability, smoothness, value relevance, timeliness, and conservatism (Dechow et al. 2010). ${ }^{5}$ While prior studies have examined non-GAAP measures in terms of their predictability, information content and valuation role, the persistence, smoothness, timeliness and conservatism of non-GAAP earnings have not typically been examined. Using a sample derived from applying text-search methods to disclosures made by ASX 500 firms from 2000-2014, we directly compare hand-collected non-GAAP earnings data from press releases with their closest GAAP equivalent. ${ }^{6}$ Since firms which disclose non-GAAP earnings do so for the same financial period as their GAAP equivalent, our comparative tests of the attributes of GAAP versus non-GAAP earnings provide a control for financial reporting incentives by holding a firm's business environment and uncertainty constant (Dechow et al. 2010).

Our comparison of non-GAAP earnings attributes with those of their closest GAAP equivalent suggests that the voluntary reporting of non-GAAP earnings reflects demand for value-relevant measures of financial performance beyond those provided by GAAP. The persistence of non-GAAP earnings is significantly higher than that for

\footnotetext{
${ }^{5}$ We do not consider traditional measures of "information content" (i.e., market reaction to earnings announcements) due to the "errors in variables" problem caused by a mismatch between the definition of realized and expected GAAP and non-GAAP earnings (Cohen et al. 2007; Bentley et al. 2018).

${ }^{6}$ For example, we carefully match pre-tax non-GAAP measures with pre-tax GAAP measures, and so on.
} 
GAAP earnings, and the difference is economically significant, accounting for about $36 \%$ of GAAP earnings persistence. Compared to their closest GAAP equivalent, non-GAAP earnings have significantly higher predictive ability for future profitability, suggesting that items excluded from the calculation of non-GAAP earnings are largely transitory and help improve the ability of current period earnings to predict future performance. Our results also show that non-GAAP earnings are smoother and less volatile compared to GAAP earnings, which is also consistent with non-GAAP earnings including less transitory items. Non-GAAP earnings are also found to be more value-relevant, as evidenced by a significantly higher regression coefficient and adjusted R-square from a regression of stock prices on book value and earnings.

On the other hand, using a regression of earnings on stock returns in the manner suggested by Basu (1997), we demonstrate that non-GAAP earnings display less evidence of conditional conservatism. As a result, we also find that non-GAAP earnings are generally less timely than their closest GAAP equivalent. This result is consistent with the view that accounting standards are conditionally conservative to an extent that exceeds the economic demand for this attribute within measures of financial performance that are used for forecasting and valuation. Overall, our comparison of non-GAAP earnings attributes with their closest GAAP equivalent provides strong support for the view that these voluntary disclosures reflect a demand for measures of financial performance that are less subject to conditional conservatism of the type inherent in GAAP, and which better facilitate the valuation role of financial reporting compared to GAAP-based earnings measures.

In additional tests we extend our analysis to compare attributes of GAAP earnings between firms that disclose non-GAAP earnings with those of non-disclosing firms. We show that GAAP earnings for firms that voluntarily disclose non-GAAP earnings are, on average, less persistent, less smooth, but more conditionally conservative than GAAP earnings reported by firms that do not voluntarily report non-GAAP earnings. These results, while subject to the myriad uncontrolled differences between firms that 
disclose non-GAAP measures and those that do not, increase our confidence that voluntary disclosure of non-GAAP earnings reflects demand for more value relevant measures of financial performance than those produced by applying GAAP. ${ }^{7}$

Finally, we investigate whether the differences we identify between the attributes of GAAP and non-GAAP earnings are in turn influenced by differences in firm size, the market-to-book ratio, industry-level propensity of non-GAAP disclosures, board independence and whether the GAAP result is a profit or loss. Existing evidence on the association between these variables and the various measures of earnings quality we examine is mixed (Dechow et al. 2010). Accordingly, it is unclear whether and how these variables would affect attributes of voluntarily disclosed non-GAAP figures. We find that differences between GAAP and non-GAAP earnings attributes are generally more evident in large firms, firms with lower market-to-book ratios, firms that report a GAAP profit rather than a loss, and in firms with relatively more independent boards. However differences in GAAP and non-GAAP attributes are generally similar regardless of the industry-propensity to disclose non-GAAP earnings.

Our paper makes several important contributions. First, to our knowledge, no prior research compares a broad set of attributes for non-GAAP performance measures with their closest GAAP equivalent, namely persistence, smoothness, value-relevance, timeliness and conservatism. Our results thus yield novel evidence on how the voluntary disclosure of non-GAAP measures of financial performance reflects a trade-off among various attributes of financial reporting, the merits of which continue to be debated (Kothari et al. 2010). By using actual disclosures of non-GAAP earnings figures collected from press releases and comparing these figures to their closest non-GAAP equivalent, we are able to provide evidence on the extent to which managers engage in voluntary disclosure directed at reversing the extent of

\footnotetext{
7 We also confirm that our results are not driven by the year of initial non-GAAP disclosure or its cessation.
} 
conditional conservatism and improving the extent to which summary measures of financial performance are value relevant or useful for forecasting. Extensive debate has occurred over the relative merit of these attributes as fundamental objectives for guiding the development of accounting standards, so directly observing how voluntary measures compare with statutory measures absent any firm-specific or time-specific differences has the potential to inform standard setters and regulators in setting reporting frameworks and developing standards for the reporting of financial performance.

Managers "undoing" of mandated GAAP to create non-GAAP performance measures brings into question the extent to which such disclosure may be self-serving, rather than incrementally informative. Prior empirical research offers at least some evidence that non-GAAP disclosures are opportunistic, as evidenced by managers using these measures to meet earnings benchmarks (Bhattacharya et al. 2004; Black and Christensen 2009; Heflin and Hsu 2008, Black et al. 2017a) or otherwise influence investor perceptions (Guillamon-Saorin et al. 2017). Similar sentiment has been expressed by accounting standard setters, who not surprisingly have recognized the increasing frequency of non-GAAP earnings disclosures as a challenge (Hoogervorst 2015; IASB 2017). However, there is also considerable evidence that suggests non-GAAP earnings are useful to investors (Bhattacharya et al. 2003; Doyle et al. 2003; Lougee and Marquardt 2004; Choi et al. 2007).

Second, our focus on multiple attributes is in contrast to prior studies, which typically examine one (or a small number) of attributes consistent with either an "informative disclosure" or "self-serving" explanation for non-GAAP disclosure. Perhaps not surprisingly, there is a strong correlation between the individual attribute (or context) examined and the conclusion reached. ${ }^{8}$ For example, published studies which consider whether non-GAAP earnings disclosures are motivated by earnings and/or impression management concerns invariably conclude that they are. However, those

\footnotetext{
${ }^{8}$ For reviews of this literature, see Black et al. (2018) and Coulton et al. (2016).
} 
which solely consider the value-relevance of accounting data invariably conclude that non-GAAP disclosures are relatively useful. Such divergent conclusions suggest these studies are unlikely to distinguish between the informative and strategic motives as explanations for disclosure of non-GAAP earnings measures. Their ability to assist standard setters and regulators to identify appropriate actions is therefore limited.

Third, our results highlight an important source of demand for less, rather than more conditional conservatism relative to that contained in GAAP earnings. Ball and Shivakumar (2005) argue that, relative to private firms, stakeholders in publicly traded firms demand more conditional conservatism. However, Heflin et al. (2015) show that analysts typically forecast earnings measures which are less conditionally conservative, but more value relevant, than GAAP earnings. Our results are consistent with those of Heflin et al., as voluntarily disclosed non-GAAP earnings similarly appear to undo some degree of conditional conservatism and increase attributes associated with value relevance in much the same way as sell-side analysts. Given analysts' preference for value relevant earnings that are more predictable and persistent, they likely represent one source of economic demand for non-GAAP earnings disclosures. Our results are also consistent with the claim by Barker and McGeachin (2015) that IFRS standards embed conditional conservatism, such that GAAP measures of performance are more consistent with the stewardship role of accounting than the valuation role, despite standard setters' suggestions to the contrary.

Finally, to the extent that a trade-off between value relevance and conditional conservatism is evidenced by voluntary disclosure of non-GAAP earnings, our results provide empirical support for the argument that a single measure of earnings is unlikely to satisfy the competing demands for measures of financial performance that serve the valuation role as well as the traditional stewardship role (Kothari et al. 2010). Explicit recognition by standard setters of this possibility has important implications for the development of regulations regarding the reporting of key performance 
measures, as well as the extent to which disaggregation of financial performance should be encouraged or even required.

The remainder of this paper is organized as follows. Section 2 presents a brief review of the non-GAAP literature, the prevailing institutional setting we examine, and the commonly used measures of earnings quality that we compare between non-GAAP earnings disclosures and their closest GAAP equivalent. Research design including sample construction, descriptive statistics, and correlation analysis are discussed in Section 3. Section 4 presents the results for tests of different aspects of earnings quality, as well as comparing these metrics between firms voluntarily disclosing non-GAAP measures and those that do not. Section 5 outlines several additional tests, including analysis of the sensitivity of our results to a number of firm-specific factors. Section 6 concludes.

\section{Background}

\subsection{Prior evidence}

As noted in section 1, there is considerable debate about whether the voluntary disclosure of non-GAAP earnings metrics primarily reflects a desire to provide useful disclosure beyond that available under GAAP, or whether such disclosure is primarily self-serving. Prior evidence offers support for both views, although it is noteworthy that prior studies do not typically try to address any form of trade-off, but rather focus on a single attribute. ${ }^{9}$

Several studies suggest that non-GAAP earnings disclosures are informative. For example, Bhattacharya et al. (2003) study a large sample of actual non-GAAP press releases for US firms, and document that, compared to street earnings,

\footnotetext{
${ }^{9}$ Our brief discussion of prior research is not intended to be comprehensive, but rather illustrative of the limitation arising from focusing on a single earnings attribute (i.e., measure of earnings quality). We also disregard studies that do not examine actual non-GAAP disclosures, but instead rely on substitutes such as analysts' forecasts. Black et al. (2018) and Coulton et al. (2016) both provide detailed summaries of prior research.
} 
non-GAAP-based forecast errors are more highly correlated with abnormal returns around earnings announcement dates and forecast revisions. Brown and Sivakumar (2003) demonstrate that non-GAAP earnings reported by US firms contain value relevant information beyond that of operating earnings. Choi et al. (2007) use a sample of non-GAAP disclosures made by UK firms, and show that items excluded from earnings by management are not value relevant. In addition, items included in voluntarily disclosed non-GAAP earnings but excluded from street earnings (as reported by Thomson Datastream) are incrementally value relevant, consistent with voluntary disclosure to adjust not only GAAP earnings, but also street earnings.

Of course, it is also not surprising that concerns are raised as to whether the voluntary disclosure of non-GAAP earnings measures is simply self-serving behaviour (Hoogervorst 2015). The deliberate "management" of GAAP earnings is constrained to some extent by the underlying accounting relation, whereby accruals reverse in future periods. In addition, accrual-based earnings management is subject to the scrutiny of auditors and regulators. Hence, the voluntary disclosure of non-GAAP earnings may be an attempt to misrepresent (i.e., overstate) financial performance.

Some support for the self-serving perspective arises from evidence that a majority of voluntarily disclosed non-GAAP earnings measures exceed GAAP earnings for the same period, and a higher percentage of non-GAAP earnings also exceed analysts' forecasts (Bhattacharya et al. 2003; Bhattacharya et al. 2004; Coulton et al. 2016). Black and Christensen (2009) document that non-GAAP earnings reported by US firms frequently exclude items that are not "one-off" in nature (i.e., research and development expenses, depreciation and amortization, and share-based compensation expenses). Moreover, these adjustments are significantly associated with firms' ability to achieve strategic earnings benchmarks that they would otherwise have missed based on GAAP earnings.

Brown et al. (2012) show that US firms are more likely to disclose a non-GAAP 
earnings measure when investor sentiment is high, thereby further reinforcing these positive perceptions. Guillamon-Saorin et al. (2017) reach a similar conclusion. They show that exclusions from non-GAAP earnings voluntarily disclosed by European firms are more persistent when a broader measure of impression management is also high. Evidence of quasi-earnings management via voluntarily disclosed non-GAAP earnings is provided by Black et al. (2017), who show that the probability of disclosing non-GAAP earnings is increasing with the extent to which managers are unable to meet earnings expectations via accrual-based and transaction-based methods of earnings management.

Overall, we simply observe that published research examining either the informative or self-serving rationales for voluntary disclosure of non-GAAP earnings typically rejects the null hypothesis (i.e., the studies report evidence consistent with the alternative hypothesis, which is either self-serving or informative disclosure). Conclusions regarding the costs or benefits of such disclosure that seemingly depend on whether the researcher examines a setting focussed on possibly self-serving behaviour (e.g., increased rates of benchmark beating) or informative disclosure (e.g., value relevance measures). Ideally, researchers would test competing hypotheses against one another. However, the existing measures used to identify either self-serving or informative disclosure rationales do not lend themselves to identifying any "net" trade-off. Hence, we take a different approach to prior studies, and compare non-GAAP earnings with their closest GAAP equivalent across several different dimensions of earnings quality.

\subsection{Our approach}

We examine a wide range of attributes that are often argued to reflect earnings quality (Dechow et al. 2010). Our focus is voluntary disclosures of non-GAAP earnings by Australian firms found in press releases outlining annual financial results. Non-GAAP disclosures in Australia are largely unregulated, other than being subject to the general principles of continuous disclosure that apply to all ASX-listed firms (Brown et al. 
1999). While the regulator issued guidance in 2011 (ASIC 2011), this was largely restricted to ensuring that a sufficient reconciliation was provided between the non-GAAP measure and the GAAP measure of financial performance. ${ }^{10}$

According to the IASB Conceptual Framework (IASB, 2018), the main objective of financial reporting "is to provide financial information about the reporting entity that is useful to existing and potential investors, lenders and other creditors in making decisions about providing resources to the entity" (para. 1.2). Within this objective there is explicit recognition of both the value relevance and stewardship roles. However, as Kothari et al. (2010) argue, there are likely inevitable conflicts between these roles, and "desirable" attributes of financial reporting measures such as earnings are therefore dependent on what is defined as the pre-eminent role. Relatedly, Dechow et al. (2010) recognize that the construct "earnings quality" is highly contextual, arguing that "higher quality earnings provide more information about the features of a firm's financial performance that are relevant to a specific decision made by a specific decision-maker" (emphasis added).

We therefore consider multiple attributes of non-GAAP earnings and compare each of these in turn with the same set of attributes displayed by the closest equivalent GAAP measure. This approach has the advantage of comparing two measures for the same set of firm-years, so the underlying business and economic environment is identical. Hence, any differences we observe between GAAP and non-GAAP earnings are a reflection of how those earnings figures are calculated (i.e., their properties), and are not due to different sets of business conditions or economic factors. Below we discuss the different attributes (i.e., aspects of earnings quality) that we examine.

\subsubsection{Earnings persistence}

Earnings persistence is widely used as a measure of earnings quality as it captures

${ }^{10}$ Coulton et al. (2016) provide a detailed overview of the history of non-GAAP disclosures by Australian firms, as well as the regulatory environment. 
earnings sustainability (Francis et al. 2004). Persistent earnings are considered to be more "sustainable" if they are recurring and useful as inputs into valuation models (e.g., Penman and Zhang 2002). Earnings persistence is also found to be positively associated with the stock price response to earnings news (Kormendi and Lipe 1987; Collins and Kothari 1989; Easton and Zmijewski 1989). However, to our knowledge, there is little research directly comparing the persistence of GAAP versus non-GAAP earnings.

Following previous research (e.g, Lev 1983; Ali and Zarowin 1992; Francis et al. 2004), we measure earnings persistence as the slope coefficient estimate, $\boldsymbol{\alpha}_{2}$, from a first-order autoregressive model (AR1) for annual split-adjusted earnings:

$$
\operatorname{Earn}_{t+1}=\alpha_{0}+\alpha_{2} \operatorname{Earn}_{t}+v_{t+1}
$$

where Earn is either GAAP earnings per share (GaapEarn), calculated as GAAP earnings divided by the number of total shares outstanding for firm $i$ at time $t$, or non-GAAP earnings per share (NGEarn), calculated as the non-GAAP earnings metric collected from the earnings press release divided by the number of total shares outstanding for firm $i$ at time $t$.

\subsubsection{Earnings predictability}

Earnings predictability is high when past earnings are reasonably good estimates of current earnings (Lipe 1990). In their survey of more than 400 US executives, Graham et al. (2005) find that earnings predictability is a primary concern among CFOs. Likewise, sell-side analysts are believed to prefer earnings measures that are relatively more predictable. Some evidence of the advantage non-GAAP earnings has for prediction purposes is offered by Lougee and Marquardt (2004). They find mixed evidence, in that current period non-GAAP earnings have no predictive power for future GAAP earnings, but have marginally significant predictive ability for future non-GAAP earnings. 
Following Lougee and Marquardt (2004), our measure of earnings predictability is derived from regressing year-ahead GAAP or non-GAAP earnings on current year GAAP and non-GAAP earnings, as follows:

$$
\operatorname{Earn}_{i, t+1}=\alpha_{0, i}+\alpha_{1, i} \operatorname{GaapEarn}_{i, t}+\alpha_{2, i} \operatorname{NGEarn}_{i, t}+\varepsilon_{i, t}
$$

where Earn is either GAAP earnings per share (GaapEarn) or non-GAAP earnings per share (NGEarn). A significant coefficient on non-GAAP earnings indicates that non-GAAP earnings have predictive ability for future profitability.

\subsubsection{Earnings smoothness}

Earnings smoothness is positively associated with earnings quality, subject to the assumption that managers use their private information about future profitability to smooth out transitory variations and thereby achieve a more representative and useful earnings figure (Francis et al. 2004). However, several cross-country studies document evidence that earnings smoothness is associated with predicted determinants of low earnings quality such as low-quality country GAAP, less

enforcement, or poor shareholder rights (Leuz et al. 2003; Lang et al. 2006; Francis and Wang 2008). Smoothness measures are based on the volatility of earnings relative to some benchmark, such as cash flows (Leuz et al. 2003; Francis et al. 2004).

Following Francis et al. (2004), we define smoothness as a ratio:

$$
\text { Earnings smoothness }_{i, t}=\sigma\left(\text { GaapEarn }_{i, t}\right) / \sigma\left(\text { NGEarn }_{i, t}\right)
$$

where Earnings smoothness ${ }_{i, t}$ is the ratio of firm $i$ 's standard deviation of GAAP earnings divided by beginning total assets, to its standard deviation of non-GAAP earnings divided by beginning total assets. A ratio of earnings smoothness higher than one indicates that non-GAAP earnings are less volatile than GAAP earnings. 


\subsubsection{Value relevance}

Value relevance is often measured as the ability of earnings to explain variation in stock prices or returns (Francis et al. 2004). Entwistle et al. (2010) find that non-GAAP earnings disclosed by large US firms are significantly more value relevant than street earnings from $\mathrm{I} / \mathrm{B} / \mathrm{E} / \mathrm{S}$, which in turn are more value relevant than GAAP earnings. Venter et al. (2014) use price-level regressions based on the Ohlson (1995) model to examine the incremental and relative value relevance of mandatory non-GAAP earnings disclosures reported by South African firms. They find that mandatorily reported non-GAAP earnings have higher value relevance than comparable GAAP earnings. ${ }^{11}$

We follow Collins et al. (1997) and conduct our tests based on the framework developed by Ohlson (1995), where firm value is a function of book value of equity and accounting earnings:

$$
\text { Price }_{i, t}=\alpha_{0, i}+\beta_{1} \text { Bookval }_{i, t}+\beta_{2} \text { Earn }_{i, t}+\varepsilon_{i, t}
$$

where Price $_{i, t}$ is the fiscal year-end closing price, adjusted for stock splits and stock dividends for firm $i$ at time $t$; Bookval $l_{i, t}$ is common equity per share for firm $i$ at time $t$; $E_{a r n}, t$ is either GAAP earnings per share (GaapEarn) or non-GAAP earnings per share (NGEarn). The estimation with higher explanatory power (adjusted $\mathrm{R}^{2}$ ) is considered to be more value relevant. In addition, we consider the difference in coefficient values, given that equation (4) is estimated for the same set of firm-years.

\subsubsection{Timeliness and conditional conservatism}

The timeliness of earnings is a reflection of the extent to which economic news is contemporaneously reflected in earnings, rather than with a lag. Prior research

\footnotetext{
${ }^{11}$ Because the disclosure of "headline earnings" is mandatory for their sample, the results of Venter et al. (2014) may not extend to settings where non-GAAP disclosure is voluntary.
} 
generally estimates timeliness by examining the explanatory power from a "reverse regression" (i.e., regressing earnings on a measure of contemporaneous economic news, most obviously the stock return) (Ball et al. 2000; Bushman et al. 2004). Conditional conservatism is therefore the asymmetric timeliness with which earnings responds to negative, as distinct from positive economic news (Basu 1997; Ball and Shivakumar 2005). While we are not aware of any examination of the extent to which non-GAAP earnings display relatively less (or more) conditional conservatism than GAAP earnings, the evidence reported by Heflin et al. (2015) suggests that sell-side analysts "undo" some GAAP requirements in forecasting street earnings, resulting in these forecasts being less conditionally conservative than GAAP.

To compare the timeliness and conservatism of non-GAAP earnings with the closest GAAP equivalent, we follow Basu (1997) and estimate the following equation:

$$
E A R N_{j, t}=\alpha_{0, j}+\alpha_{1, j} N E G_{j, t}+\beta_{1, j} R E T_{j, t}++\beta_{2, j} N E G_{j, t} * R E T_{j, t}+\varsigma_{j, t}(5)
$$

where $R E T_{j, t}$ is firm j's 12-month return ending three months after the end of fiscal year $\mathrm{t} ; N E G_{j, t}$ is equal to one if $R E T_{j, t}$ is negative and 0 otherwise; and $E A R N_{j, t}$ is GAAP earnings per share (GaapEarn) or non-GAAP earnings per share (NGEarn). We compare the adjusted R-squares from estimates using non-GAAP and GAAP earnings respectively to assess differences in timeliness. The regression coefficient $\beta_{2}$ provides a measure of conditional conservatism. A higher value of $\beta_{2}$ indicates greater conservatism.

\section{Research design}

\subsection{Sample}

Voluntary disclosures of non-GAAP earnings data are identified from earnings announcements by ASX 500 firms from 2000 to 2014. Using text search technology available from SIRCA, we are able to identify all instances within full-year profit 
announcements where a non-GAAP earnings measure was reported. A comprehensive dictionary of terms commonly used to describe non-GAAP earnings such as "cash earnings", "core earnings", "underlying earnings" and "normalized profit" were used in the initial search stage. ${ }^{12}$ The final sample consists of 11,648 firm-year observations for the period of 2000-2014. Given the variation in disclosed non-GAAP earnings (including whether they are pre or post-tax), we then hand collect the GAAP measure which most closely corresponds to the non-GAAP measure. ${ }^{13}$ This procedure increases our confidence that we are comparing like-for-like figures, which is an important assumption for the "horse race" approach we use.

We use the Morningstar DatAnalysis Database to extract other accounting information. Following prior literature, we exclude firm-years with (1) negative total assets; (2) negative book value of equity; (3) negative or missing sales revenue; and (4) extreme values of return-on-equity or net profit margin higher or equal to $100 \%$. To mitigate the undue influence of outliers, we winsorise the top and bottom one percentile of key variables used in the regression analysis. ${ }^{14}$

\subsection{Descriptive statistics}

Panel A of Table 1 provides descriptive statistics for our data. The average firm has a price of $\$ 2.69$ per share and a book value of equity per share of $\$ 1.27$. The mean dollar value per share of GAAP earnings is $\$ 0.27$, while the mean dollar value per share of non-GAAP earnings is $\$ 0.32$. The median value of non-GAAP earnings is also higher than for GAAP earnings ( $\$ 0.17$ vs. $\$ 0.14)$. This indicates that on average our sample firms report higher non-GAAP earnings than GAAP earnings. ${ }^{15}$

\footnotetext{
12 In the initial stages of identifying non-GAAP earnings disclosures, two research assistants (to cross-check) and one senior researcher examined each case to ensure that an appropriate match occurred with the closest GAAP equivalent. Further details on the data collection process are outlined in Coulton et al. (2016).

13 Our "matching" of GAAP and non-GAAP is also verified by reference to firms' own reconciliation of non-GAAP and GAAP.

14 Our results remain quantitatively similar if we trim the top and bottom percentiles of key variables or keep them in the analysis.

15 As expected, we also find that GAAP earnings and non-GAAP earnings are highly correlated, with a significant Person (Spearman) correlation coefficient of 0.824 (0.834).
} 
Panel B reports the frequency of non-GAAP disclosures across different industries. Industries are classified based on the SIRCA industry classification codes. Australian companies in financial industries (e.g., Banks and Insurance) are found to be most likely to present non-GAAP information, followed by companies in Utilities $(50 \%)$, Media (49\%), Food and Staples Retailing (49\%) and Materials excluding Metals and Mining (49\%). On the other hand, ASX 500 companies in Pharmaceuticals and Biotechnology (9\%), Metals and Mining (10\%), Technology, Hardware and Equipment (15\%) and Energy (19\%) are least likely to disclose non-GAAP earnings. Non-GAAP exclusions are predominately positive in all industries except Automobile and Components, further suggesting that non-GAAP earnings typically exceed their closest GAAP equivalent. Further analysis (untabulated) shows that non-GAAP exclusions decrease by $\$ 0.012$ per share for firms from "frequent disclosing" industries, accounting for a reduction of $21 \%$ compared to the average non-GAAP exclusions ( $\$ 0.058$ per share).

[Table 1 about here]

\section{Results}

\subsection{The quality of GAAP vs. non-GAAP earnings}

Table 2 reports our comparison of non-GAAP earnings disclosures with their closest GAAP equivalent for each individual attribute (i.e., measures of earnings quality). These results reflect time-series averages derived from annual estimations, which also allow us to estimate any time-trend in each attribute for GAAP earnings or non-GAAP earnings individually, as well as in the differences between the two measures of earnings. We report coefficient values with probability levels in parentheses.

Panel A of Table 2 reports our tests of earnings persistence, using a regression of 
either GAAP or non-GAAP earnings on their respective lagged values (equation (1)). The results show that, on average, non-GAAP earnings are significantly more persistent than GAAP earnings (0.937 vs. 0.698). The difference in persistence between GAAP and non-GAAP earnings (0.240) is economically large, accounting for around $36 \%$ of GAAP earnings persistence. Overall, it appears that non-GAAP earnings are substantially more persistent than their closest GAAP equivalent.

Tests of predictability (equation (2)) are reported in Panel B of Table 2, derived from regressing future profitability (either GAAP or non-GAAP earnings) on both current period GAAP earnings and non-GAAP earnings (Lougee and Marquardt 2004). The estimation of equation (2) indicates that GAAP and non-GAAP earnings both have predictive ability for future GAAP earnings $($ coefficient $=0.171, p$-value $=0.002$ for GAAP earnings; coefficient $=0.788, p$-value $=0.000$ for non-GAAP earnings). Notably though, non-GAAP earnings measures have higher predictive ability than GAAP earnings $(0.788$ vs. 0.171$)$, indicating that the exclusion of certain items from GAAP earnings to construct non-GAAP earnings improves the ability of current period earnings to predict future profitability. In terms of predicting future non-GAAP earnings, the coefficient on non-GAAP earnings is found to be positive and significant, while the coefficients on GAAP earnings are insignificant in most years, and on average are not significantly different from zero. When we focus on the adjusted R-square as an indicator of predictability, it is evident that non-GAAP earnings are significantly more predictable overall than earnings reported in compliance with GAAP. Overall, our results in Panels A and B of Table 2 support the view that, relative to their closest GAAP equivalent, non-GAAP earnings are more persistent and more predictable.

Our comparison of the smoothness of non-GAAP earnings relative to their closest GAAP equivalent (equation (3)) is reported in Panel $\mathrm{C}$ of Table 2. The results show that, on average, non-GAAP earnings are significantly smoother than GAAP earnings. This decrease in volatility compared to GAAP earnings is consistent with non-GAAP 
earnings containing less transitory items. However, we also observe a significant time trend, whereby the relative smoothness of non-GAAP earnings declines over the period we examine. Further examination suggests that this reflects some increase in the volatility of non-GAAP earnings, rather than any decline in the volatility of earnings reported in compliance with GAAP.

In Panel D of Table 2 we report the results from our tests of value relevance (equation (4)). This entails regressing price on both book value and earnings, where earnings is either the voluntarily disclosed non-GAAP measure or its closest GAAP equivalent. Turning first to GAAP earnings, we find evidence of value relevance with a positive and significant average coefficient of 5.707. However, when GAAP earnings are replaced by non-GAAP earnings, the average coefficient on non-GAAP earnings is 11.677, which is also significantly higher than that for GAAP earnings. Although the stronger result for non-GAAP earnings may partially reflect a decreased role for book value (the book value coefficient declines from 1.378 to 0.619 ), we also observe a significant increase in the model adjusted R-square when non-GAAP earnings are used in place of GAAP earnings $(0.834$ vs. 0.731$)$. This result further supports the view that the value relevance of non-GAAP earnings exceeds that for GAAP earnings. It is also of interest to observe that the difference in explanatory power shows evidence of having increased over time, which is consistent with some divergence in earnings properties important to the stewardship and value relevance roles.

Estimations of timeliness and conservatism are reported in Panel E of Table 2. Turning first to timeliness, we find the adjusted R-square from estimating equation (5) using GAAP earnings is significantly higher compared to estimations using non-GAAP earnings (0.098 vs. 0.066), suggesting that GAAP earnings are more timely than non-GAAP earnings. We also observe a significant decline over time in the timeliness of non-GAAP earnings, with a negative and significant time trend of -0.005 ( $p$-value $=0.027$ ). In contrast, there is no significant decline over time in the timeliness of GAAP earnings. 
When we focus on our measure of conservatism, the results in Panel E of Table 2 provide strong evidence consistent with non-GAAP earnings being less conditionally conservative than their closest GAAP equivalent. For GAAP earnings, the coefficient associated with stock returns restricted only to negative values (i.e., the incremental responsiveness to a measure of bad economic news, $\beta_{2}$ ) is 0.808 , which is higher than that for non-GAAP earnings $(0.585)$. The difference, while economically large, is only marginally statistically significant $(p$-value $=0.129)$. However, this reflects at least in part a decline over time in the extent to which non-GAAP earnings are less conditionally conservative, as evidenced by the significant negative coefficient from a simple time trend regression of the annual differences.

[Table 2 about here]

Overall, we characterize the results presented in Table 2 as being supportive of the argument that voluntarily disclosed non-GAAP earnings are more useful for forecasting and valuation than their closest GAAP equivalent. However, the results presented in Table 2 are based on time-series averages from annual regressions, while the $p$-values and statistics are calculated using the time-series coefficients and adjusted R-squares in the Fama-MacBeth (1973) fashion. An alternative approach is to use a pooled regression, and include industry and year dummies to control for unobserved heterogeneity. The results are presented in Table 3. Consistent with those reported in Table 2, the results support the argument that non-GAAP earnings reported by Australian firms are more persistent and smoother, and have higher predictive power over future underlying performance, suggesting that non-GAAP earnings have higher quality than GAAP earnings. In addition, the results suggest that the timeliness and conservatism of non-GAAP earnings are significantly lower than those for GAAP earnings.

[Table 3 about here] 


\subsection{Disclosers versus non-disclosers}

Inferences drawn from our primary tests reported in Tables 2 and 3 are based solely on a comparison of non-GAAP earnings and their closest GAAP equivalent. While the setting facilitates a simple "horse race" design (e.g., which earnings measure "wins" for a given attribute), it is limited to those firms that voluntarily disclose non-GAAP earnings. The results could also be due in part to differences in the way GAAP is applied to firms disclosing non-GAAP earnings compared to non-disclosers. The existence of such differences may also add weight to the argument that voluntary disclosure of non-GAAP earnings is motivated by a desire to provide a measure of earnings that is more value relevant and less conditionally conservative. If so, we would expect that firms disclosing non-GAAP earnings would demonstrate less persistent or value-relevant, but more timely and conservative GAAP earnings than companies without non-GAAP disclosures.

We therefore repeat the analyses reported in Table 3 for all ASX 500 firms over the period 2000-2014, and include an indicator variable, $N G \_d u m m y$, which takes a value of one if firms voluntarily disclose non-GAAP information, and zero otherwise. The results are provided in Table 4. They suggest that GAAP earnings in companies with voluntary non-GAAP disclosures are found to be less persistent, less smooth but more conservative. While these results are descriptive only, and do not control in any way for differences between disclosing and non-disclosing firm-years, we view them as consistent with the view that GAAP earnings, to a large extent, reflect the stewardship role and the supply of non-GAAP earnings is a response to economic demand for information that is not satisfied by GAAP earnings measures. In addition, the results are in sharp contrast to the findings for non-GAAP earnings discussed previously, suggesting that our evidence that non-GAAP earnings are more persistent, predictable and value-relevant, but less timely and less conservative is not attributable to the differential attributes of GAAP earnings between non-GAAP disclosing firms and non-disclosing firms. 
[Table 4 about here]

\section{Additional Analysis}

\subsection{Cross-sectional variation in earnings quality differences}

The above analyses suggest substantial differences between the attributes of GAAP and non-GAAP earnings. In this section, we investigate whether such differences vary across several firm-specific characteristics. While we regard this evidence as exploratory, we consider the effect of differences in firm size, the market-to-book ratio, industry-level propensity of non-GAAP disclosures, accounting loss versus profit, and board independence. As summarized in Dechow et al. (2010), evidence on the association between these variables and different indicators of earnings quality is quite mixed. Accordingly, it is unclear whether and how these variables would affect differences in the attributes of non-GAAP and GAAP earnings that we document.

Table 5 repeats the analysis of Table 3, but separates observations into those with above or below median firm size, measured as equity market capitalization. Firm size can be negatively associated with earnings quality because larger firms would make income-deceasing accounting method choices in response to greater regulatory scrutiny (Watts and Zimmerman 1986). On the other hand, it is suggested that size and earnings quality is positively related because small firms are more likely to have internal control deficiencies (Ball and Foster 1982; Doyle et al. 2007). Of course, one difficulty with this reasoning is that earnings quality has several dimensions, and these are also context specific. Our results indicate that the differences between attributes of GAAP and non-GAAP earnings are more evident in large firms. Compared to GAAP earnings, non-GAAP figures in large firms tend to be more persistent, predictive, and value-relevant and smoother, but have a lower degree of conservatism. These patterns are not as strong when analysis is restricted to firm-years with below median size. 
[Table 5 about here]

Table 6 repeats the analysis in Table 3, but with separate estimates for firms with above and below median values of the market-to-book ratio. The market-to-book ratio is often used as a measure of relative firm valuation. Firms with high market-to-book ratio are considered as those with relatively high valuations, thereby facing higher pressure from capital market participants. Accordingly, firms with higher market-to-book ratios are more likely to voluntarily disclose favourable information (e.g., non-GAAP numbers) to meet or beat market expectation, even though such information may not be of high quality. We generally find that the differences between non-GAAP earnings and GAAP earnings reported in Table 3 are prevalent for both higher and lower market-to-book firms.

[Table 6 about here]

It is evident from Table 1 (Panel B) that the propensity to provide a non-GAAP earnings measure varies across industries. It is possible that as more firms voluntarily disclose non-GAAP figures within an industry, the more pressure their industry peers face to similarly provide non-GAAP disclosures. To the extent non-GAAP disclosure is mimicking industry peers, we expect that observable differences in attributes between GAAP and non-GAAP earnings will be attenuated (i.e., there would be a bias against finding the type of differences reported in Tables 2 and 3). Nevertheless, we consider possible industry-specific differences in how attributes of non-GAAP earnings differ from GAAP. We classify firm-years into two groups based on the industry-level disclosure propensity of non-GAAP earnings, where the industry propensity of non-GAAP disclosures is measured as the percentage of firms voluntarily disclosing non-GAAP figures in each of the 25 SIRCA industries. The results in Table 7 suggest that the differences documented in Table 3 are evident across industry groups, regardless of whether there is a relatively high or low 
propensity to disclose non-GAAP earnings.

[Table 7 about here]

Over the past several decades, the proportion of Australian firms reporting negative income has increased significantly (Balkrishna et al. 2007). Attributes of accounting information for loss firms are found to be substantially different from profitable firms. For example, Hayn (1995) shows that, for loss firms, accounting earnings are less informative about firms' future prospects. Barth et al. (2018) show that accounting earnings has little relevance for firms reporting a financial loss. Givoly and Hayn (2000) and Balkrishna et al. (2007) demonstrate that the increased proportion of listed firms reporting a loss is consistent with an increased degree of accounting conservatism among US and Australian listed firms respectively. Hence, GAAP earnings may become less useful in predicting future performance but more conservative among firms reporting negative GAAP earnings. In addition, our previous findings suggest that non-GAAP earnings are generally more persistent, predictable and value relevant, but are less conservative and less timely compared to their closest GAAP equivalent. Since the difference between GAAP and non-GAAP earnings for profitable and loss firms depends on the incremental information contained in non-GAAP earnings, we expect to observe that the difference between GAAP and non-GAAP earnings is more significant among loss firms in terms of the persistence and predictability of earnings, but less significant in terms of conservatism.

Table 8 repeats the analysis in Table 3 , but with separate estimates for firms reporting a positive GAAP profit after tax and those making a loss. Consistent with Barth et al. (2018) and Hayn (1995), we find that disclosed earnings (either GAAP or non-GAAP earnings) tend to be less predictive and useful for firms reporting a loss. However, we find that the differences between non-GAAP earnings and GAAP earnings in terms of persistence, predictability and relevance are only evident among profitable firms. 
Such differences become insignificant in loss-making firms. This finding indicates that both GAAP and non-GAAP earnings tend to be less useful for firms reporting a financial loss. ${ }^{16}$ In addition, we find that non-GAAP earnings are less conservative for both profitable and loss firms, but less timely for profitable firms only. The results reinforce the stewardship role of accounting earnings inherent within GAAP, and that voluntarily disclosed non-GAAP earnings reflect information users' demand for forecasting and valuation irrespective of the signs of economic signals (positive or negative) conveyed by reported earnings.

[Table 8 about here]

Finally, we also investigate the extent to which differences in attributes of non-GAAP and GAAP earnings differ according to board independence. Boards with more independent directors are expected to be better monitors of the financial reporting system within a firm and constrain self-serving disclosure of non-GAAP earnings. Frankel et al. (2011) show that the persistence of non-GAAP earnings is positively associated with a measure of board independence. We therefore examine the extent to which the results reported in Table 3 vary according to whether board independence (measured as the percentage of outside directors) is above or below the median. Our results, reported in Table 9, suggest that the differences we document between GAAP and non-GAAP earnings are not restricted to firms with more independent boards. Much the same pattern of increased value relevance and predictability, but less conditional conservatism for non-GAAP earnings is evident for firms with both relatively more and relatively less independent boards.

\section{[Table 9 about here]}

\subsection{Robustness analysis}

We consider the robustness of our results to three additional concerns. These are the

\footnotetext{
${ }^{16}$ Our results in this respect differ from those reported by Leung and Veenman (2018) for US firms.
} 
switch from Australian-sourced accounting standards to IFRS standards, the introduction of regulatory guidance for voluntary non-GAAP earnings disclosures, and the effect of initiating or ceasing non-GAAP disclosure. We briefly discuss each of these in turn. ${ }^{17}$

Coulton et al. (2016) provide descriptive evidence of non-GAAP earnings disclosures increasing after the mandatory introduction of IFRS for Australian firms (i.e., after 2005). We therefore examine whether differences in attributes between GAAP and non-GAAP earnings measures differ systematically between financial years where IFRS is the basis of Australian GAAP, and those preceding that change. The results suggest that the differences we document between GAAP and non-GAAP earnings occur both before and after the mandatory introduction of IFRS, although in some cases they are more evident in the periods after the adoption of IFRS.

In addition to the changes to Australian GAAP following the mandatory introduction of IFRS, any differences between GAAP and non-GAAP earnings might also be influenced by regulatory intervention (Kolev 2008). However, the only intervention of note during our test period was the release by ASIC of Regulatory Guide 230 in 2011, and we have noted that the main purpose of this release appears to have been to encourage adequate reconciliation between non-GAAP and GAAP measures, rather than providing guidelines as to the determination of non-GAAP earnings. Nevertheless, we check whether our primary results are impacted by the release of ASIC RG 230. Our results show that the release of RG 230 had very little effect on the difference between GAAP and non-GAAP earnings.

Finally, we carefully assess whether our main results may be attributable to companies who initiate and provide non-GAAP earnings information beyond the year of the initial disclosure, and companies who stop the provision of non-GAAP earnings after such voluntary disclosure in the previous three years. We repeat our analysis in

\footnotetext{
${ }^{17}$ For brevity we do not include detailed results. These are available from the authors on request.
} 
Table 3, but with the added inclusion of two indicator variables, Initiate and Terminate, along with their interaction terms. Initiate is an indicator equal to one if the firm-year is one where disclosure of non-GAAP earnings commenced, and zero otherwise. Terminate equals one if a firm discloses non-GAAP earnings in year $t$, but terminates this form of voluntary disclosure in year $t+1$, otherwise zero. The results suggest that our conclusions are not affected by the initiation or termination of non-GAAP disclosures. Non-GAAP earnings are more persistent, predictable and value-relevant, but less timely and less conservative, regardless of the temporal disclosure pattern.

\section{Conclusion}

The voluntary disclosure of non-GAAP earnings has become increasingly common, but there is considerable debate as to the underlying motive for these disclosures. The voluntary disclosure of earnings measures which do not comply with GAAP has also caused significant angst for standard setters (Hoogervorst 2015). Prior research has largely failed to help resolve this tension, yielding evidence consistent with both informative and self-serving rationales. Our approach contrasts with earlier research. Instead of testing either the self-serving or informative disclosure rationales, we use a large sample of earnings press releases to directly compare several attributes of non-GAAP earnings with their closest GAAP equivalent. This approach has the advantage of providing a "controlled" comparison, as the two earnings measures in question are reported for the same set of firm-years. Hence, we are able to conduct a "horse race" between the two measures, where the "track" can be one of several different (and potentially conflicting) earnings attributes.

Using a sample of ASX 500 firms disclosing non-GAAP earnings from 2000-2014, we find consistent evidence that non-GAAP earnings are more useful for valuation than their GAAP equivalent. Compared to GAAP earnings, non-GAAP measures are more persistent, more predictable, smoother and more value-relevant. These are 
attributes that are likely important if earnings is useful for valuation and/or forecasting (i.e., the value relevance role identified by the IASB Conceptual Framework). However, improvements in these aspects appear to be at the expense of timeliness and conditional conservatism, both of which are argued to be important attributes of GAAP that helps fulfil the traditional stewardship role.

We characterize our results as being consistent with a trade-off, whereby the overriding purpose of non-GAAP earnings disclosures is to address one role of financial reporting (value relevance) which is, to some extent, restricted by conditional conservatism inherent in GAAP as well as the way managers and auditors have incentives to apply GAAP in a conservative manner. This result is consistent with the argument that a single performance measure is unlikely to satisfy the requirements of both the value relevance and stewardship roles of accounting (Kothari et al. 2010). Our results therefore speak to the extent to which standard setters might encourage, or even mandate multiple measures of earnings, possibly via a set of subtotals (IASB 2018b).

Our results also support the conclusions of Heflin et al. (2015), who argue that security analysts' focus on "street earnings" in order to undo the effects of conditionally conservative GAAP. While much research has focussed on the private (or contracting) demand for conservatism, our results support the claim by Barker and McGeachin (2015) that, despite the IASB's apparent rejection of conditional conservatism as a desirable attribute of accounting, IFRS standards actually impose measurement rules that lead to conditional conservatism. Perhaps ironically, our evidence suggests that managers voluntarily provide performance measures to better satisfy the valuation role of accounting that the IASB sees as paramount.

Our research also highlights several opportunities for further investigation. Much of our analysis is descriptive, while we rely on relatively common methods used to capture various dimensions of earnings quality. Alternative methods for capturing 
these dimensions, as well as entirely different attributes (e.g., earnings comparability and information content) are areas that warrant further analysis. We do not systematically explore differences between firms that voluntarily disclose non-GAAP earnings and those that do not. In addition, we do not consider the extent to which firms that do not disclose non-GAAP earnings measures use other forms of voluntary disclosure to convey additional information about non-GAAP earnings. The trade-off between additional earnings measures versus enhanced disclosure is a topic worthy of further investigation. Finally, we do not examine whether voluntarily disclosed non-GAAP earnings measures are also used for internal performance evaluation purposes (Coulton et al. 2016), something which, prima facie, appears inconsistent with non-GAAP earnings being more focussed on valuation than stewardship. 


\section{References}

Ali, A., and P. Zarowin. 1992. The role of earnings levels in annual earnings-returns studies. Journal of Accounting Research 30 (2):286-296.

Australian Securities and Investments Commission (ASIC). 2011. RG 230 Disclosing non-IFRS financial information.

Balkrishna, H., J. Coulton, and S. Taylor. 2007. Accounting losses and earnings conservatism: Evidence from Australian GAAP. Accounting and Finance 47 (3):381-400.

Ball, R. and G. Foster. 1982. Corporate financial reporting: A methodological review of empirical research. Journal of Accounting Research 20:161-234.

Ball, R., S. Kothari, and A. Robin. 2000. The effect of international institutional factors on properties of accounting earnings. Journal of Accounting and Economics 29 (1):1-51.

Ball, R., and L. Shivakumar. 2005. Earnings quality in UK private firms: comparative loss recognition timeliness. Journal of Accounting and Economics 39 (1):83-128.

Barker, R., and A. McGeachin. 2015. An analysis of concepts and evidence on the question of whether IFRS should be conservative. Abacus 51 (2):169-207.

Barth, M., K. Li, and C. McClure. 2018. Evolution in value relevance of accounting information. Working paper, Stanford University.

Basu, S. 1997. The conservatism principle and the asymmetric timeliness of earnings. Journal of Accounting and Economics 24 (1):3-37.

Bentley, J., T. Christensen, K. Gee, and B. Whipple. 2018. Disentangling managers' and analysts' non-GAAP reporting. Journal of Accounting Research 56 (4):1039-1081.

Bhattacharya, N., E. Black, T. Christensen, and C. Larson. 2003. Assessing the relative informativeness and permanence of pro forma earnings and GAAP operating earnings. Journal of Accounting and Economics 36 (1):285-319.

Bhattacharya, N., E. Black, T. Christensen, and R. Mergenthaler. 2004. Empirical evidence on recent trends in pro forma reporting. Accounting Horizons 18 (1):27-43.

Black, D., and T. Christensen. 2009. US managers' use of 'pro forma'adjustments to meet strategic earnings targets. Journal of Business Finance \& Accounting 36 (3-4):297-326.

Black, D., T. Christensen, J. Ciesielski, and B. Whipple. 2018. Non-GAAP reporting: evidence from acedmia and current practice. Journal of Business Finance and Accounting 45 (3-4): 259-294.

Black, E., T. Chistensen, T. Joo, and R. Schmardebeck. 2017. The relation between earnings management and non-GAAP reporting. Contemporary Accounting Research 34 (2): 750-782.

Brown, N., T. Christensen, W. Elliott, and R. Mergenthaler. 2012. Investor sentiment and pro forma earnings disclosures. Journal of Accounting Research 50 
(1): $1-40$.

Brown, L., and K. Sivakumar. 2003. Comparing the value relevance of two operating income measures. Review of Accounting Studies 8 (4):561-572.

Brown, P., S. Taylor, and T. Walter. 1999. The impact of statutory sanctions on the level and information content of voluntary corporate disclosure. Abacus 35 (2):138-162.

Bushman, R., Q. Chen, E. Engel, and A. Smith. 2004. Financial accounting information, organizational complexity and corporate governance systems. Journal of Accounting and Economics 37 (2):167-201.

Choi, Y.-S., S. Lin, M. Walker, and S. Young. 2007. Disagreement over the persistence of earnings components: evidence on the properties of management-specific adjustments to GAAP earnings. Review of Accounting Studies 12 (4):595-622.

Cohen, D., R. Hann, and M. Ogneva. 2007. Another look at GAAP versus the Street: an empirical assessment of measurement error bias. Review of Accounting Studies 12 (2-3):271-303.

Collins, D., and S.P. Kothari. 1989. An analysis of intertemporal and cross-sectional determinants of earnings response coefficients. Journal of Accounting and Economics 11 (2):143-181.

Collins, D., E. Maydew, and I. Weiss. 1997. Changes in the value-relevance of earnings and book values over the past forty years. Journal of Accounting and Economics 24 (1):39-67.

Copper, S. 2015. A tale of prudence. IASB Investor Perspectives June 2015., London UK.

Coulton, J., A. Ribeiro, Y. Shan, and S. Taylor. 2016. The Rise and Rise of Non-GAAP Disclosure: A survey of Australian practice and its implications. Sydney, Australia: Chartered Accountants Australia and New Zealand.

Dechow, P., W. Ge, and C. Schrand. 2010. Understanding earnings quality: A review of the proxies, their determinants and their consequences. Journal of Accounting and Economics 50 (2):344-401.

Doyle, J., W. Ge, and S. McVay. 2007. Accruals quality and internal control over financial reporting. The Accounting Review 82 (5):1141-1170.

Doyle, J., J. Jennings, and M. Soliman. 2013. Do managers define non-GAAP earnings to meet or beat analyst forecasts? Journal of Accounting and Economics 56 (1):40-56.

Doyle, J., R. Lundholm, and M. Soliman. 2003. The Predictive Value of Expenses Excluded from Pro Forma Earnings. Review of Accounting Studies 8 (23):145-174.

Easton, P., and M. Zmijewski. 1989. Cross-sectional variation in the stock market response to accounting earnings announcements. Journal of Accounting and Economics 11 (2-3):117-141.

Entwistle, G., G. Feltham, and C. Mbagwu. 2010. The Value Relevance of Alternative Earnings Measures: A Comparison of Pro Forma, GAAP, and I/B/E/S Earnings. Journal of Accounting, Auditing and Finance 25 (2): 261-288.

Fama, E., and J. MacBeth. 1973. Risk, return, and equilibrium: Empirical tests. 
Journal of Political Economy 81 (3):607-636.

Francis, J., R. LaFond, P. Olsson, and K. Schipper. 2004. Costs of equity and earnings attributes. The Accounting Review 79 (4):967-1010.

Francis, J., and D. Wang. 2008. The joint effect of investor protection and big 4 audits on earnings quality around the world. Contemporary Accounting Research 25 (1):157-191.

Frankel, R., S. McVay, and M. Soliman. 2011. Non-GAAP Earnings and Board Independence. Review of Accounting Studies 16 (4): 719-744.

Graham, J., C. Harvey, and S. Rajgopal. 2005. The economic implications of corporate financial reporting. Journal of Accounting and Economics 40 (1):3-73.

Guillamon-Saorin, E., H. Isidro, and A. Marques. 2017. Impression management and non-GAAP disclosure in earnings announcements. Journal of Business Finance and Accounting 44 (3):448-479.

Heflin, F. and C. Hsu, C. 2008. The Impact of the SEC's Regulation of Non-GAAP Disclosures. Journal of Accounting and Economics 46 (2):349-365.

Heflin, F., C. Hsu, and Q. Jin. 2015. Accounting conservatism and street earnings. Review of Accounting Studies 20 (4): 674-709.

Hoogervorst, H. 2015. Mind the Gap (Between non-GAAP and GAAP). Korean Accounting Review International Symposium, Seoul, Korea.

Hoogervorst, H. 2016. Performance reporting and the pitfalls of non-GAAP metrics. European Accounting Association Conference, Maastricht.

Hsu, C., and W. Kross. 2011. The Market Pricing of Special Items that are Included in versus Excluded from Street Earnings. Contemporary Accounting Research 28 (3):990-1017.

International Accounting Standards Board (IASB). 2017. Disclosure InitiativePrinciples of Disclosure. Discussion Paper March 2017.

International Accounting Standards Board (IASB). 2018a. Conceptual Framework for Financial Reporting.

International Accounting Standards Board (IASB). 2018b. IASB Agenda Item 21B June 2018: Primary Financial Statements: Project Summary.

Kothari, S.P., K. Ramanna, and D. Skinner. 2010. Implications for GAAP from an analysis of positive research in accounting. Journal of Accounting and Economics 50 (2-3):246-286.

Kolev, K., C. Marquardt, and S. McVay. 2008. SEC Scrutiny and the Evolution of Non-GAAP Reporting. The Accounting Review 83 (1): 157-84.

Kormendi, R., and R. Lipe. 1987. Earnings innovations, earnings persistence, and stock returns. Journal of Business 60 (3):323-345.

Lai, C., Y. Li, Y. Shan, and S. Taylor. 2013. Costs of mandatory international financial reporting standards: Evidence of reduced accrual reliability. Australian Journal of Management 38 (3):491-521.

Lang, M., J. Raedy, and W. Wilson. 2006. Earnings management and cross listing: Are reconciled earnings comparable to US earnings? Journal of Accounting and Economics 42 (1):255-283. 
Leung, E., and D. Veenman. 2018. Non-GAAP earnings disclosure in loss firms. Journal of Accounting Research 56 (4):1083-1137.

Leuz, C., D. Nanda, and P. Wysocki, D. 2003. Earnings management and investor protection: an international comparison. Journal of Financial Economics 69 (3):505-527.

Lev, B. 1983. Some economic determinants of time-series properties of earnings. Journal of Accounting and Economics (5):31-48.

Lipe, R. 1990. The relation between stock returns and accounting earnings given alternative information. The Accounting Review 65(1):49-71.

Lougee, B., and C. Marquardt. 2004. Earnings informativeness and strategic disclosure: An empirical examination of "pro forma" earnings. The Accounting Review 79 (3):769-795.

Ohlson, J. 1995. Earnings, book values, and dividends in equity valuation. Contemporary Accounting Research 11 (2):661-687.

Penman, S., and X. Zhang. 2002. Accounting conservatism, the quality of earnings, and stock returns. The Accounting Review, 77(2):237-264.

Ruddock, C., S.J. Taylor, and S.L. Taylor. 2006. Nonaudit services and earnings conservatism: Is auditor independence impaired? Contemporary Accounting Research 23 (3):701-746.

Venter, E., D. Emanuel, and S. Cahan. 2014. The value relevance of mandatory nonGAAP earnings. Abacus 50 (1):1-24.

Young, S. 2014. The drivers, consequences and policy implications of non-GAAP earnings reporting. Accounting and Business Research, 44 (4): 444-465.

Watts, R. 2003. Conservatism in accounting part I: Explanations and implications. Accounting Horizons 17 (3):207-221.

Watts, R., and J. Zimmerman. 1986. Positive accounting theory. Englewood Cliffs, NY: Prentice-Hall. 
Variable

Panel A: Earnings variable

GaapEarn

NGEarn

Exclusions

Panel B: Firm's Characteristics

RET

$N E G$

Price

Bookval

Sizemv

$M t b$

Boardind

Propensity
Measurement

GaapEarn is GAAP earnings per share, calculated as the disclosed corresponding GAAP earnings together with non-GAAP earnings collected from a firm's earnings press release divided by the number of total shares outstanding NGEarn is non-GAAP earnings per share, calculated as the non-GAAP earnings metric collected from earnings press release divided by the number of total shares outstanding Exclusion is the difference between NGEarn and GaapEarn

A firm's 12 month stock return ending three months after fiscal year-end

$N E G$ equals to 1 if $R E T$ is negative and 0 otherwise

Price is the closing price at the fiscal year-end

Bookval is the book value of equity per share, calculated as total shareholders' equity divided by the number of total shares outstanding

Sizemv is a firm's size measured by the log of its market capitalisation

$M t b$ is the market to book ratio

Board independence is the percentage of independent directors in the board

The industry-level disclosure propensity of non-GAAP earnings, measured as the percentage of firms voluntarily disclosing non-GAAP figures in each of the 25 SIRCA industries 


\section{Table 1: Summary statistics}

Panel A presents the summary statistics of earnings measures and firms characteristics. Definitions of all variables can be found in the Appendix. The number of observations is 11,648 .

\begin{tabular}{ccccccc}
\hline Variable & N & Mean & Median & Std Dev & Q1 & Q3 \\
\hline Earnings Variable & & & & & & \\
GaapEarn & 2,576 & 0.268 & 0.136 & 0.580 & 0.017 & 0.345 \\
NGEarn & 2,576 & 0.323 & 0.172 & 0.475 & 0.066 & 0.388 \\
Exclusions & 2,576 & 0.058 & 0.015 & 0.260 & 0.000 & 0.086 \\
Firm Characteristics Variable & & & & & \\
Bookval & 10,122 & 1.266 & 0.453 & 2.126 & 0.121 & 1.404 \\
Price & 10,127 & 2.692 & 0.800 & 5.369 & 0.200 & 2.660 \\
NEG & 9,632 & 0.466 & 0.000 & 0.499 & 0.000 & 1.000 \\
Additional Variable & & & & & & \\
Sizemv & 10,125 & 18.618 & 18.536 & 1.9724 & 17.238 & 19.925 \\
Mtb & 10,127 & 2.808 & 1.687 & 3.5203 & 0.956 & 3.115 \\
Boardind & 9,065 & 0.716 & 0.750 & 0.1683 & 0.600 & 0.833 \\
\hline
\end{tabular}


Panel B presents the frequency of non-GAAP disclosures and the amount of non-GAAP exclusions across industries. Definitions of all variables can be found in the Appendix. The number of observations is 11,648 .

\begin{tabular}{|c|c|c|c|c|}
\hline SIRCA Industry Sectors & $\mathbf{N}$ & $\begin{array}{l}\% \text { of non-GAAP } \\
\text { disclosures }\end{array}$ & $\begin{array}{c}\text { Non-GAAP } \\
\text { exclusions } \\
\text { (Mean) }\end{array}$ & $\begin{array}{l}\text { Non-GAAP } \\
\text { exclusions } \\
\text { (Median) }\end{array}$ \\
\hline Energy & 1,040 & $19 \%$ & 0.010 & 0.004 \\
\hline Materials (excl. Metals \& Mining) & 344 & $49 \%$ & 0.002 & 0.003 \\
\hline Metals \& Mining & 2,742 & $10 \%$ & 0.058 & 0.008 \\
\hline Capital Goods & 702 & $34 \%$ & 0.033 & 0.007 \\
\hline Commercial Services \& Supplies & 538 & $39 \%$ & 0.035 & 0.010 \\
\hline Transportation & 228 & $28 \%$ & 0.009 & 0.002 \\
\hline Automobile \& Components & 70 & $46 \%$ & -0.041 & 0.004 \\
\hline Consumer Durables \& Apparel & 161 & $32 \%$ & 0.037 & 0.011 \\
\hline Consumer Services & 307 & $43 \%$ & 0.015 & 0.005 \\
\hline Media & 363 & $49 \%$ & 0.139 & 0.004 \\
\hline Retailing & 446 & $32 \%$ & 0.060 & 0.007 \\
\hline Food \& Staples Retailing & 87 & $49 \%$ & 0.013 & 0.005 \\
\hline Food \& Drug Retailing & 352 & $35 \%$ & 0.027 & 0.004 \\
\hline Health Care Equipment \& Services & 454 & $26 \%$ & 0.026 & 0.011 \\
\hline Pharmaceuticals \& Biotechnology & 505 & $9 \%$ & 0.042 & 0.001 \\
\hline Banks & 24 & $50 \%$ & 0.031 & 0.000 \\
\hline Diversified Financials & 442 & $39 \%$ & 0.100 & 0.003 \\
\hline Insurance & 12 & $83 \%$ & 0.001 & 0.005 \\
\hline $\begin{array}{l}\text { Real Estate excluding Investment } \\
\text { Trusts }\end{array}$ & 39 & $51 \%$ & 0.004 & 0.000 \\
\hline Real Estate Investment Trusts & 2 & $50 \%$ & 0.000 & 0.000 \\
\hline Software \& Services & 617 & $20 \%$ & 0.099 & 0.024 \\
\hline Technology Hardware \& Equipment & 158 & $15 \%$ & 0.067 & 0.010 \\
\hline Telecommunication Services & 277 & $31 \%$ & 0.098 & 0.003 \\
\hline Utilities & 204 & $50 \%$ & 0.014 & 0.005 \\
\hline No Specified & 13 & $8 \%$ & 1.437 & 1.437 \\
\hline
\end{tabular}




\section{Table 2: Annual regressions: the quality of GAAP vs. Non-GAAP earnings}

This table reports the results of annual regressions that examine the quality of GAAP earnings and non-GAAP earnings. Definitions of all variables can be found in the Appendix. The reported coefficients and adjusted $\mathrm{R}$-squares are the time-series average from the annual regressions, and $p$-value in parentheses are calculated based on the time-series coefficients and adjusted R-squares. $* * *(* *, *)$ indicates significant at the $1 \%(5 \%, 10 \%)$ level for two-tailed test.

\begin{tabular}{|c|c|c|c|c|c|c|}
\hline & \multicolumn{2}{|c|}{ GAAP } & \multicolumn{2}{|c|}{ Non GAAP } & \multicolumn{2}{|c|}{ Non-GAAP vs GAAP } \\
\hline & Average & Time trend & Average & Time trend & Average & Time trend \\
\hline $\begin{array}{l}\text { Panel A: Persist } \\
\text { Persistence }\left(\alpha_{1}\right)\end{array}$ & $\begin{array}{c}\mathbf{0 . 6 9 8} * * * \\
(0.000)\end{array}$ & $\begin{array}{c}0.000 \\
(0.973)\end{array}$ & $\begin{array}{c}\mathbf{0 . 9 3 7 * * * *} \\
(0.000)\end{array}$ & $\begin{array}{c}0.005 \\
(0.706)\end{array}$ & $\begin{array}{c}\mathbf{0 . 2 4 0 * * *} \\
(0.001)\end{array}$ & $\begin{array}{c}0.004 \\
(0.545)\end{array}$ \\
\hline \multicolumn{7}{|c|}{ Panel B: Predictability } \\
\hline GaapEarn $\left(\alpha_{1}\right)$ & $\begin{array}{c}\mathbf{0 . 1 7 1} * * * \\
(0.002)\end{array}$ & $\begin{array}{l}-0.010 \\
(0.402)\end{array}$ & $\begin{array}{l}-0.002 \\
(0.953)\end{array}$ & $\begin{array}{l}-0.009 \\
(0.258)\end{array}$ & - & - \\
\hline NGEarn $\left(\alpha_{2}\right)$ & $\begin{array}{c}\mathbf{0 . 7 8 8} * * * \\
(0.000)\end{array}$ & $\begin{array}{c}0.015 \\
(0.526)\end{array}$ & $\begin{array}{c}\mathbf{0 . 9 3 7} * * * \\
(0.000)\end{array}$ & $\begin{array}{c}0.014 \\
(0.309)\end{array}$ & - & - \\
\hline Adj. $R^{2}$ & $\begin{array}{c}\mathbf{0 . 5 8 0} * * * \\
(0.000)\end{array}$ & $\begin{array}{c}0.005 \\
(0.686)\end{array}$ & $\begin{array}{c}\mathbf{0 . 7 9 7} * * * \\
(0.000)\end{array}$ & $\begin{array}{c}0.007 \\
(0.382)\end{array}$ & $\begin{array}{c}\mathbf{0 . 2 1 5} * * * \\
(0.000)\end{array}$ & $\begin{array}{c}0.002 \\
(0.813)\end{array}$ \\
\hline \multicolumn{7}{|c|}{ Panel C: Smoothness } \\
\hline Smoothness & - & - & - & - & $\begin{array}{c}1.242 * * * \\
(0.000)\end{array}$ & $\begin{array}{c}-\mathbf{0 . 0 1 2} * * \\
(0.029)\end{array}$ \\
\hline \multicolumn{7}{|c|}{ Panel D: Relevance } \\
\hline Bookval $\left(\beta_{1}\right)$ & $\begin{array}{c}1.378 * * * \\
(0.000)\end{array}$ & $\begin{array}{c}-0.033 \\
(0.106)\end{array}$ & $\begin{array}{c}\mathbf{0 . 6 1 9} * * * \\
(0.000)\end{array}$ & $\begin{array}{l}-0.046 \\
(0.104)\end{array}$ & - & - \\
\hline GaapEarn $\left(\beta_{2}\right)$ & $\begin{array}{c}\mathbf{5 . 7 0 7} * * * \\
(0.000)\end{array}$ & $\begin{array}{c}0.049 \\
(0.683)\end{array}$ & - & - & - & - \\
\hline NGEarn $\left(\beta_{2}\right)$ & - & - & $\begin{array}{c}11.677 * * * \\
(0.000)\end{array}$ & $\begin{array}{c}0.059 \\
(0.782)\end{array}$ & $\begin{array}{c}\mathbf{5 . 9 7 1} * * * \\
(0.000)\end{array}$ & $\begin{array}{c}0.010 \\
(0.948)\end{array}$ \\
\hline Adj. $R^{2}$ & $\begin{array}{c}\mathbf{0 . 7 3 1} * * * \\
(0.000)\end{array}$ & $\begin{array}{c}0.005 \\
(0.171)\end{array}$ & $\begin{array}{c}\mathbf{0 . 8 3 4} * * * \\
(0.000)\end{array}$ & $\begin{array}{c}\mathbf{0 . 0 1 2} * * * \\
(0.005)\end{array}$ & $\begin{array}{c}\mathbf{0 . 1 0 3}^{* * *} \\
(0.000)\end{array}$ & $\begin{array}{c}\mathbf{0 . 0 0 6}^{* * *} \\
(0.040)\end{array}$ \\
\hline \multicolumn{7}{|c|}{ Panel E: Timeliness and Conservatism } \\
\hline $\operatorname{NEG}\left(\alpha_{1}\right)$ & $\begin{array}{c}\mathbf{- 0 . 0 8 4} * * \\
(0.034)\end{array}$ & $\begin{array}{c}0.006 \\
(0.524)\end{array}$ & $\begin{array}{c}-\mathbf{- 0 . 0 4 4 *} \\
(0.083)\end{array}$ & $\begin{array}{c}-0.001 \\
(0.853)\end{array}$ & - & - \\
\hline $\operatorname{RET}\left(\beta_{1}\right)$ & $\begin{array}{c}-\mathbf{0 . 0 9 0} * * * * \\
(0.008)\end{array}$ & $\begin{array}{l}-0.007 \\
(0.306)\end{array}$ & $\begin{array}{c}-\mathbf{0 . 0 9 5} * * * * \\
(0.004)\end{array}$ & $\begin{array}{l}-0.008 \\
(0.240)\end{array}$ & - & - \\
\hline NEG*RET $\left(\beta_{2}\right)$ & $\begin{array}{c}\mathbf{0 . 8 0 8}^{* * * *} \\
(0.000)\end{array}$ & $\begin{array}{l}\text { 0.050* } \\
(0.070)\end{array}$ & $\begin{array}{c}\mathbf{0 . 5 8 5} * * * \\
(0.000)\end{array}$ & $\begin{array}{c}0.018 \\
(0.315)\end{array}$ & $\begin{array}{l}-0.223 \\
(0.129)\end{array}$ & $\begin{array}{c}-\mathbf{- 0 . 0 3 1} * * \\
(0.019)\end{array}$ \\
\hline Adj. $R^{2}$ & $\begin{array}{c}\mathbf{0 . 0 9 8} * * * \\
(0.000)\end{array}$ & $\begin{array}{c}-0.002 \\
(0.406) \\
\end{array}$ & $\begin{array}{c}\mathbf{0 . 0 6 6} * * * * \\
(0.000)\end{array}$ & $\begin{array}{c}-\mathbf{0 . 0 0 5 * *} \\
(0.027) \\
\end{array}$ & $\begin{array}{l}\mathbf{- 0 . 0 3 1 *} \\
(0.069) \\
\end{array}$ & $\begin{array}{c}-\mathbf{- 0 . 0 0 3 *} \\
(0.070) \\
\end{array}$ \\
\hline
\end{tabular}

For earnings persistence, we estimate the following regression:

$$
\operatorname{Earn}_{t+1}=\alpha_{0}+\alpha_{1} \text { Earn }_{t}+v_{t+1} \quad(1)
$$

where Earn is GAAP earnings per share (GaapEarn), calculated as the disclosed GAAP earnings together with non-GAAP earnings collected from a firm's earnings press release divided by the number of total shares outstanding for firm i at time t, or non-GAAP earnings per share (NGEarn), calculated as the non-GAAP earnings metric collected from earnings press release divided by the number of total shares outstanding for firm $i$ at time $t$; $v$ is the error term.

For earnings predictability, we estimate the regression models as follows:

We calculate earnings smoothness as:

$$
\operatorname{Earn}_{i, t+1}=\alpha_{0, i}+\alpha_{1, i} \operatorname{GaapEarn}_{i, t}+\alpha_{2, i} \operatorname{NGEarn}_{i, t}+\varepsilon_{i, t} \quad \text { (2) }
$$

Earnings smoothness $s_{i, t}=\sigma\left(\right.$ GaapEarn $\left._{i, t}\right) / \sigma(N G$ Earni, $) \quad$ (3)

where Earnings smoothness $s_{i, t}$ is the ratio of firm i's standard deviation of GAAP earnings over the most recent three years divided by beginning total assets, to its standard deviation of non-GAAP earnings divided by beginning total assets.

Value relevance is estimated using the following models:

Price $_{i, t}=\alpha_{0, i}+\beta_{1}$ Bookval $_{i, t}+\beta_{2}$ Earn $_{i, t}+\varepsilon_{i, t} \quad$ (4)

where Price $_{i, t}$ is the fiscal year-end closing price, adjusted for stock splits and stock dividends for firm i at time $\mathrm{t}$; Bookval ${ }_{i, t}$ is common equity per share for firm $\mathrm{i}$ at time $\mathrm{t}$; and $\varepsilon_{i, t}$ is the error term.

With respect to timeliness and conservatism, we use the following models: $E A R N_{j, t}=\alpha_{0, j}+\alpha_{1, j} N E G_{j, t}+\beta_{1, j} R E T_{j, t}++\beta_{2, j} N E G_{j, t} * R E T_{j, t}+\varsigma_{j, t}(5)$

where $N E G_{j, t}$ equal to 1 if $R E T$ is negative and 0 otherwise; $R E T_{j, t}$ is firm j's 12 -month return ending three months after the end of fiscal year $\mathrm{t}$. 


\section{Table 3: Pooled regressions: the quality of GAAP vs. Non-GAAP earnings}

This table reports the results of pooled time-series and cross-sectional regressions that examine the quality of GAAP earnings and non-GAAP earnings. Industry (based on the 25 SIRCA industry classification) and year fixed effects are included for all earnings quality measures. Definitions of all variables can be found in the Appendix. $* * *(* *, *)$ indicates significant at the $1 \%(5 \%, 10 \%)$ level for two-tailed test.

\begin{tabular}{|c|c|c|c|}
\hline & GAAP & Non-GAAP & Non-GAAP vs GAAP \\
\hline $\begin{array}{l}\text { Panel A: Persistence } \\
\text { Persistence }\left(\alpha_{1}\right)\end{array}$ & $\begin{array}{c}\mathbf{0 . 6 4 3} * * * \\
(0.000)\end{array}$ & $\begin{array}{c}\mathbf{0 . 9 0 1 * * *} \\
(0.000)\end{array}$ & $\begin{array}{c}\mathbf{0 . 2 5 8 * * *} \\
(0.000)\end{array}$ \\
\hline \multicolumn{4}{|l|}{ Panel B: Predictability } \\
\hline $\operatorname{GaapEarn}\left(\alpha_{1}\right)$ & $\begin{array}{c}\mathbf{0 . 1 2 4} * * * \\
(0.000)\end{array}$ & $\begin{array}{l}-0.005 \\
(0.791)\end{array}$ & - \\
\hline $\operatorname{NGEarn}\left(\alpha_{2}\right)$ & $\begin{array}{c}\mathbf{0 . 8 0 3} * * * \\
(0.000)\end{array}$ & $\begin{array}{c}\mathbf{0 . 9 0 5} * * * \\
(0.000)\end{array}$ & - \\
\hline Adj. $R^{2}$ & 0.570 & 0.797 & $\begin{array}{c}\mathbf{0 . 2 2 7} * * * \\
(0.000)\end{array}$ \\
\hline
\end{tabular}

\section{Panel C: Smoothness}

$\begin{array}{llll}\text { Smoothness } & \text { - } & - & 1.845\end{array}$

$(0.207)$

\begin{tabular}{|c|c|c|c|}
\hline \multicolumn{4}{|c|}{ Panel D: Relevance } \\
\hline Bookval $\left(\beta_{1}\right)$ & $\begin{array}{c}1.419 * * * \\
(0.000)\end{array}$ & $\begin{array}{c}\mathbf{0 . 6 9 8} * * * \\
(0.000)\end{array}$ & - \\
\hline GaapEarn $\left(\beta_{2}\right)$ & $\begin{array}{c}\mathbf{5 . 2 4 8}^{*} * * \\
(0.000)\end{array}$ & - & - \\
\hline NGEarn $\left(\beta_{2}\right)$ & - & $\begin{array}{c}10.868 * * * \\
(0.000)\end{array}$ & $\begin{array}{c}\mathbf{5 . 6 2 0} * * * \\
(0.000)\end{array}$ \\
\hline Adj. $R^{2}$ & 0.746 & 0.839 & $\begin{array}{c}\mathbf{0 . 0 9 3} * * * \\
(0.000)\end{array}$ \\
\hline \multicolumn{4}{|c|}{ Panel E: Timeliness and Conservatism } \\
\hline $\operatorname{NEG}\left(\alpha_{1}\right)$ & $\begin{array}{c}\mathbf{- 0 . 0 7 8 * *} \\
(0.029)\end{array}$ & $\begin{array}{c}-0.046 \\
(0.113)\end{array}$ & - \\
\hline $\operatorname{RET}\left(\beta_{1}\right)$ & $\begin{array}{c}-\mathbf{0 . 1 0 4} * * * \\
(0.000)\end{array}$ & $\begin{array}{c}-\mathbf{0 . 1 0 0} * * * \\
(0.000)\end{array}$ & - \\
\hline NEG*RET $\left(\beta_{2}\right)$ & $\begin{array}{c}\mathbf{0 . 8 3 2} * * * \\
(0.000)\end{array}$ & $\begin{array}{c}\mathbf{0 . 5 5 3} * * * \\
(0.000)\end{array}$ & $\begin{array}{c}-\mathbf{0 . 2 7 9} * * * \\
(0.000)\end{array}$ \\
\hline Adj. $\mathrm{R}^{2}$ & 0.131 & 0.117 & $\begin{array}{c}-\mathbf{0 . 0 1 4} * * * \\
(0.000)\end{array}$ \\
\hline
\end{tabular}

For earnings persistence, we estimate the following regression:

$$
\operatorname{Earn}_{t+1}=\alpha_{0}+\alpha_{l} \operatorname{Earn}_{t}+v_{t+1} \quad(1)
$$

where Earn is GAAP earnings per share (GaapEarn), calculated as the disclosed GAAP earnings together with non-GAAP earnings collected from a firm's earnings press release divided by the number of total shares outstanding for firm $\mathrm{i}$ at time $\mathrm{t}$, or non-GAAP earnings per share (NGEarn), calculated as the non-GAAP earnings metric collected from earnings press release divided by the number of total shares outstanding for firm $i$ at time $t ; v$ is the error term. For earnings predictability, we estimate the regression models as follows:

We calculate earnings smoothness as:

$$
\operatorname{Earn}_{i, t+1}=\alpha_{0, i}+\alpha_{1, i} \operatorname{GaapEarn}_{i, t}+\alpha_{2, i} \operatorname{NGEarn}_{i, t}+\varepsilon_{i, t}
$$

Earnings smoothness ${ }_{i, t}=\sigma\left(\right.$ GaapEarn $\left._{i, t}\right) / \sigma($ NGEarni, $t)$

where Earnings smoothness $i_{i, t}$ is the ratio of firm i's standard deviation of GAAP earnings over the most recent three years divided by beginning total assets, to its standard deviation of non-GAAP earnings divided by beginning total assets. Value relevance is estimated using the following models:

$$
\text { Price }_{i, t}=\alpha_{0, i}+\beta_{1} \text { Bookval }_{i, t}+\beta_{2} \text { Earn }_{i, t}+\varepsilon_{i, t} \text { (4) }
$$

where Price $_{i, t}$ is the fiscal year-end closing price, adjusted for stock splits and stock dividends for firm i at time t; Bookval $l_{i, t}$ is common equity per share for firm $\mathrm{i}$ at time $\mathrm{t}$; and $\varepsilon_{i, t}$ is the error term. With respect to timeliness and conservatism, we use the following models:

$E A R N_{j, t}=\alpha_{0, j}+\alpha_{1, j} N E G_{j, t}+\beta_{1, j} R E T_{j, t}++\beta_{2, j} N E G_{j, t} * R E T_{j, t}+\varsigma_{j, t}(5)$ where $N E G_{j, t}$ equals 1 if $R E T$ is negative and $0 ; R E T_{j, t}$ is firm j's 12 -month return ending 3 months after the end of fiscal year $\mathrm{t}$. 


\section{Table 4: Earnings quality of GAAP earnings for firms with and without non-GAAP disclosures}

This table reports the results of pooled time-series and cross-sectional regressions that examine the quality of GAAP. $N G \_d u m m y$ is an indicator variable equal to one if the firm discloses non-GAAP earnings in the year, and zero otherwise. Firm and year fixed effects are included for all earnings quality measures. Definitions of all variables can be found in the Appendix. *** $(* *, *)$ indicates significant at the $1 \%(5 \%, 10 \%)$ level for two-tailed test.

\begin{tabular}{|c|c|}
\hline & GAAP Earnings \\
\hline \multirow{3}{*}{$\begin{array}{c}\text { Persistence } \\
\text { Net Income }\left(\alpha_{1}\right)\end{array}$} & (Dependent var. $=$ Net Income $_{t+1}$ ) \\
\hline & $0.814^{* * *}$ \\
\hline & $(0.000)$ \\
\hline \multirow[t]{2}{*}{$N G \_d u m m y\left(\alpha_{2}\right)$} & $0.047 * * *$ \\
\hline & $(0.000)$ \\
\hline \multirow[t]{2}{*}{$\operatorname{Loss}\left(\alpha_{3}\right)$} & $-0.048 * * *$ \\
\hline & $(0.000)$ \\
\hline \multirow[t]{2}{*}{ Net Income $\times N G \_d u m m y\left(\beta_{1}\right)$} & $-0.067 * * *$ \\
\hline & $(0.000)$ \\
\hline \multirow[t]{2}{*}{ Net Income $\times$ Loss $\left(\beta_{2}\right)$} & $-0.657 * * *$ \\
\hline & $(0.000)$ \\
\hline \multirow[t]{2}{*}{ Net Income $\times N G_{-}$dummy $\times \operatorname{Loss}\left(\beta_{3}\right)$} & $0.364 * * *$ \\
\hline & $(0.000)$ \\
\hline Adj. $\mathrm{R}^{2}$ & $0.814 * * *$ \\
\hline \multirow{3}{*}{$\begin{array}{l}\text { Smoothness } \\
\text { Intercept }\end{array}$} & (Dependent var. = Earnings smoothness) \\
\hline & $4.886^{* * *}$ \\
\hline & $(0.000)$ \\
\hline \multirow[t]{2}{*}{$N G \_d u m m y$} & $-0.399 * *$ \\
\hline & $(0.018)$ \\
\hline Adj. $R^{2}$ & 0.026 \\
\hline Relevance & (Dependent var. $=$ Price $)$ \\
\hline \multirow[t]{2}{*}{ Bookval $\left(\alpha_{1}\right)$} & $1.150^{* * *}$ \\
\hline & $(0.000)$ \\
\hline \multirow[t]{2}{*}{$\operatorname{Earn}\left(\alpha_{2}\right)$} & $6.053 * * *$ \\
\hline & $(0.000)$ \\
\hline \multirow[t]{2}{*}{$N G \_d u m m y\left(\alpha_{3}\right)$} & 0.096 \\
\hline & $(0.221)$ \\
\hline \multirow[t]{2}{*}{$N G_{-}$dummy $\times$Bookval $\left(\beta_{1}\right)$} & $-0.068 *$ \\
\hline & $(0.078)$ \\
\hline \multirow[t]{2}{*}{$N G \_d u m m y \times \operatorname{Earn}\left(\beta_{2}\right)$} & $1.750 * * *$ \\
\hline & $(0.000)$ \\
\hline Adj. $\mathrm{R}^{2}$ & 0.715 \\
\hline \multirow{3}{*}{$\begin{array}{c}\text { Timeliness and Conservatism } \\
\text { NEG }\left(\alpha_{1}\right)\end{array}$} & (Dependent var. $=$ Net Income) \\
\hline & $-0.027 * *$ \\
\hline & $(0.012)$ \\
\hline \multirow[t]{2}{*}{$\operatorname{RET}\left(\alpha_{2}\right)$} & $-0.024 * * *$ \\
\hline & $(0.000)$ \\
\hline \multirow[t]{2}{*}{$N G \_d u m m y\left(\alpha_{3}\right)$} & $0.192 * * *$ \\
\hline & $(0.000)$ \\
\hline \multirow[t]{2}{*}{$N E G \times R E T\left(\beta_{1}\right)$} & $0.249 * * *$ \\
\hline & $(0.000)$ \\
\hline \multirow[t]{2}{*}{$\mathrm{NEG} \times N G \_d u m m y\left(\beta_{2}\right)$} & -0.015 \\
\hline & $(0.483)$ \\
\hline \multirow[t]{2}{*}{$R E T \times N G \_d u m m y\left(\beta_{3}\right)$} & $-0.048 * * *$ \\
\hline & $(0.002)$ \\
\hline \multirow[t]{2}{*}{$N E G \times R E T \times N G \_d u m m y\left(\beta_{4}\right)$} & $0.375 * * *$ \\
\hline & $(0.000)$ \\
\hline Adj. $R^{2}$ & 0.191 \\
\hline
\end{tabular}


For earnings persistence, we estimate the following regression:

$$
\begin{aligned}
& \text { Net Income }_{t+1}=\alpha_{0}+\alpha_{1} \text { Net Income }_{t}+\alpha_{2} N \text { Idummy }_{t}+\alpha_{3} \text { Loss }_{t}+\beta_{1} \text { Net Income }_{t} * N G_{-} \text {dummy } y_{t}+\beta_{2} \text { Net }_{\text {In }} \\
& \text { Income }^{*} \text { Loss } t_{t}+\beta_{3} \text { Net Income } \text { In }^{*} N G_{-} \text {dummy } \text { I }_{t} * \text { Loss } t_{t}+v_{t+1}
\end{aligned}
$$

where Net Income is GAAP net profit divided by total assets; Loss is an indicator variable equal to one if the firm reports a loss in the year, and zero otherwise; $v$ is the error term. For earnings smoothness, we estimate the following regression:

$$
\text { Earnings smoothness } i_{i, t}=\alpha_{0}+\alpha_{1} N G_{-} \text {dummy } y_{t}+v_{t}
$$

Earnings smoothness is the standard deviation of net income before extraordinary items divided by beginning total assets, to its standard deviation of cash flows from operation divided by beginning total assets. Value relevance is estimated using the following models:

Price $_{t}=\alpha_{0}+\alpha_{1}$ Bookval $+\alpha_{2}$ Earn $_{t}+\alpha_{3} N G_{-}$dummy $_{t}+\beta_{1}$ Bookval $_{t} * N G_{-}$dummy $_{t}+\beta_{2}$ Earn $_{t} * N G_{-}$dummy $y_{t}+\varepsilon_{t}$

where Price is the fiscal year-end closing price, adjusted for stock splits and stock dividends; Bookval $\mathrm{l}_{i, t}$ is common equity per share for firm i at time t; Earn is GAAP earnings per share; and $\varepsilon_{i, t}$ is the error term. With respect to timeliness and conservatism, we use the following models:

$$
\begin{gathered}
E A R N_{t}=\alpha_{0}+\alpha_{1} N E G_{t}+\alpha_{2} R E T_{t}+\alpha_{3} N G_{-} d u m m y_{t}+\beta_{1} N E G_{t} * R E T_{t}+\beta_{2} N E G_{t} * N G_{-} d u m m y_{t}+\beta_{3} R E T_{t} * \\
N G_{-} d u m m y_{t}+\beta_{4} R E T_{t} * N E G_{t} * N G_{-} d u m m y_{t}+\varepsilon_{t}
\end{gathered}
$$

where $N E G_{j, t}$ equal to 1 if $R E T$ is negative; $R E T_{j, t}$ is firm j's 12 -month return ending three months after the end of fiscal year $\mathrm{t}$. 


\section{Table 5: Pooled regressions comparing the quality of GAAP vs. Non-GAAP earnings: Small vs. Large firms}

This table reports the results of pooled time-series and cross-sectional regressions that examine the quality of GAAP earnings and non-GAAP earnings. Industry (based on the 25 SIRCA industry classification) and year fixed effects are included for all earnings quality measures. Definitions of all variables can be found in the Appendix. *** $(* *, *)$ indicates significant at the $1 \%(5 \%, 10 \%)$ level for two-tailed test.

\begin{tabular}{|c|c|c|c|c|c|c|}
\hline \multirow[b]{3}{*}{ Panel A: Persistence } & \multicolumn{2}{|c|}{ GAAP } & \multicolumn{2}{|c|}{ Non-GAAP } & \multicolumn{2}{|c|}{ Non-GAAP vs. GAAP } \\
\hline & Small & Large & Small & Large & Small & Large \\
\hline & & & & & & \\
\hline Persistence $\left(\alpha_{1}\right)$ & $\begin{array}{c}\mathbf{0 . 5 1 3 * * *} \\
(0.000)\end{array}$ & $\begin{array}{c}\mathbf{0 . 6 2 4} * * * \\
(0.000)\end{array}$ & $\begin{array}{c}\mathbf{0 . 3 5 8}^{* * *} \\
(0.000)\end{array}$ & $\begin{array}{c}\mathbf{0 . 9 1 5 * * *} \\
(0.000)\end{array}$ & $\begin{array}{l}-0.155 \\
(0.577)\end{array}$ & $\begin{array}{l}\mathbf{0 . 2 9 1} * * * \\
(0.000)\end{array}$ \\
\hline \multicolumn{7}{|c|}{ Panel B: Predictability } \\
\hline GaapEarn $\left(\alpha_{1}\right)$ & $\begin{array}{c}\mathbf{0 . 2 2 1} * * * \\
(0.000)\end{array}$ & $\begin{array}{c}\mathbf{0 . 1 0 5 * * *} \\
(0.005)\end{array}$ & $\begin{array}{c}0.043 \\
(0.279)\end{array}$ & $\begin{array}{l}-0.000 \\
(0.984)\end{array}$ & - & - \\
\hline NGEarn $\left(\alpha_{2}\right)$ & $\begin{array}{c}\mathbf{0 . 6 3 8} * * * \\
(0.000)\end{array}$ & $\begin{array}{c}\mathbf{0 . 8 1 9} * * * \\
(0.000)\end{array}$ & $\begin{array}{c}\mathbf{0 . 3 0 6 * * *} \\
(0.000)\end{array}$ & $\begin{array}{c}\mathbf{0 . 9 1 5} * * * \\
(0.000)\end{array}$ & - & - \\
\hline Adj. $R^{2}$ & 0.389 & 0.557 & 0.281 & 0.816 & $\begin{array}{l}-\mathbf{- 0 . 1 0 8} * * * \\
(0.000)\end{array}$ & $\begin{array}{c}\mathbf{0 . 2 5 9} * * * \\
(0.000)\end{array}$ \\
\hline \multicolumn{7}{|c|}{ Panel C: Smoothness } \\
\hline Smoothness & - & - & - & - & $\begin{array}{l}-0.655 \\
(0.840)\end{array}$ & $\begin{array}{c}2.771 \\
(0.111)\end{array}$ \\
\hline \multicolumn{7}{|c|}{ Panel D: Relevance } \\
\hline Bookval $\left(\beta_{1}\right)$ & $\begin{array}{c}\mathbf{0 . 8 5 4} * * * \\
(0.000)\end{array}$ & $\begin{array}{c}1.257 * * * \\
(0.000)\end{array}$ & $\begin{array}{c}\mathbf{0 . 7 4 8} * * * \\
(0.000)\end{array}$ & $\begin{array}{c}\mathbf{0 . 5 2 2} * * * \\
(0.000)\end{array}$ & - & - \\
\hline GaapEarn $\left(\beta_{2}\right)$ & $\begin{array}{l}1.030 * * * \\
(0.000)\end{array}$ & $\begin{array}{l}5.940 * * * \\
(0.000)\end{array}$ & - & - & - & - \\
\hline NGEarn $\left(\beta_{2}\right)$ & - & - & $\begin{array}{c}2.373 * * * \\
(0.000)\end{array}$ & $\begin{array}{l}11.757 * * * \\
(0.000)\end{array}$ & $\begin{array}{l}1.343 * * \\
(0.027)\end{array}$ & $\begin{array}{c}\mathbf{5 . 8 1 7} * * * \\
(0.000)\end{array}$ \\
\hline Adj. $R^{2}$ & 0.556 & 0.736 & 0.584 & 0.843 & $\begin{array}{c}0.028 \\
(0.126)\end{array}$ & $\begin{array}{c}\mathbf{0 . 1 0 7} * * * \\
(0.000)\end{array}$ \\
\hline \multicolumn{7}{|c|}{$\begin{array}{l}\text { Panel E: Timeliness and } \\
\text { Conservatism }\end{array}$} \\
\hline $\operatorname{NEG}\left(\alpha_{1}\right)$ & $\begin{array}{l}-0.021 \\
(0.507)\end{array}$ & $\begin{array}{l}-0.047 \\
(0.392)\end{array}$ & $\begin{array}{l}-0.019 \\
(0.336)\end{array}$ & $\begin{array}{l}-0.020 \\
(0.664)\end{array}$ & - & - \\
\hline $\operatorname{RET}\left(\beta_{1}\right)$ & $\begin{array}{l}-\mathbf{- 0 . 0 4 2 *} \\
(0.067)\end{array}$ & $\begin{array}{l}\mathbf{- 0 . 0 9 7 *} \\
(0.054)\end{array}$ & $\begin{array}{l}-\mathbf{0 . 0 3 1} * * \\
(0.025)\end{array}$ & $\begin{array}{l}-\mathbf{0 . 0 9 7 * *} \\
(0.020)\end{array}$ & - & - \\
\hline NEG*RET $\left(\beta_{2}\right)$ & $\begin{array}{c}\mathbf{0 . 4 4 2} * * * \\
(0.000)\end{array}$ & $\begin{array}{l}1.094 * * * \\
(0.000)\end{array}$ & $\begin{array}{c}\mathbf{0 . 1 7 3} * * * \\
(0.000)\end{array}$ & $\begin{array}{c}\mathbf{0 . 6 5 1} * * * \\
(0.000)\end{array}$ & $\begin{array}{l}-\mathbf{- 0 . 2 6 9} * * * \\
(0.000)\end{array}$ & $\begin{array}{c}-\mathbf{- 0 . 4 4 3 * * * *} \\
(0.000)\end{array}$ \\
\hline Adj. $R^{2}$ & 0.193 & 0.132 & 0.184 & 0.131 & $\begin{array}{c}\mathbf{- 0 . 0 0 9} * * * \\
(0.000)\end{array}$ & $\begin{array}{c}-\mathbf{0 . 0 0 1} * * * \\
(0.000)\end{array}$ \\
\hline
\end{tabular}

For earnings persistence, we estimate the following regression:

$$
\operatorname{Earn}_{t+1}=\alpha_{0}+\alpha_{1} \operatorname{Earn}_{t}+v_{t+1}
$$

where Earn is GAAP earnings per share (GaapEarn), calculated as the disclosed GAAP earnings together with non-GAAP earnings collected from a firm's earnings press release divided by the number of total shares outstanding for firm i at time $t$, or non-GAAP earnings per share (NGEarn), calculated as the non-GAAP earnings metric collected from earnings press release divided by the number of total shares outstanding for firm i at time $t ; v$ is the error term. For earnings predictability, we estimate the regression models as follows:

We calculate earnings smoothness as:

$$
\operatorname{Earn}_{i, t+1}=\alpha_{0, i}+\alpha_{1, i} \operatorname{GaapEarn}_{i, t}+\alpha_{2, i} \operatorname{NGEarn}_{i, t}+\varepsilon_{i, t}
$$

$$
\text { Earnings smoothness }_{i, t}=\sigma\left(\text { GaapEarn }_{i, t}\right) / \sigma(N G \text { Earni,t }) \quad \text { (3) }
$$

where Earnings smoothness $s_{i, t}$ is the ratio of firm i's standard deviation of GAAP earnings over the most recent three years divided by beginning total assets, to its standard deviation of non-GAAP earnings divided by beginning total assets. Value relevance is estimated using the following models:

$$
\text { Price }_{i, t}=\alpha_{0, i}+\beta_{1} \text { Bookval }_{i, t}+\beta_{2} \text { Earn }_{i, t}+\varepsilon_{i, t} \quad \text { (4) }
$$

where Price $_{i, t}$ is the fiscal year-end closing price, adjusted for stock splits and stock dividends for firm i at time t; Bookval $l_{i, t}$ is common equity per share for firm $\mathrm{i}$ at time $\mathrm{t}$; and $\varepsilon_{i, t}$ is the error term. For timeliness and conservatism, we use the following models: 


\section{Table 6: Pooled regressions comparing the quality of GAAP vs. Non-GAAP earnings: High vs. Low market-to-book ratio firms}

This table reports the results of pooled time-series and cross-sectional regressions that examine the quality of GAAP earnings and non-GAAP earnings. Industry (based on the 25 SIRCA industry classification) and year fixed effects are included for all earnings quality measures. Definitions of all variables can be found in the Appendix. *** $(* *, *)$ indicates significant at the $1 \%(5 \%, 10 \%)$ level for two-tailed test.

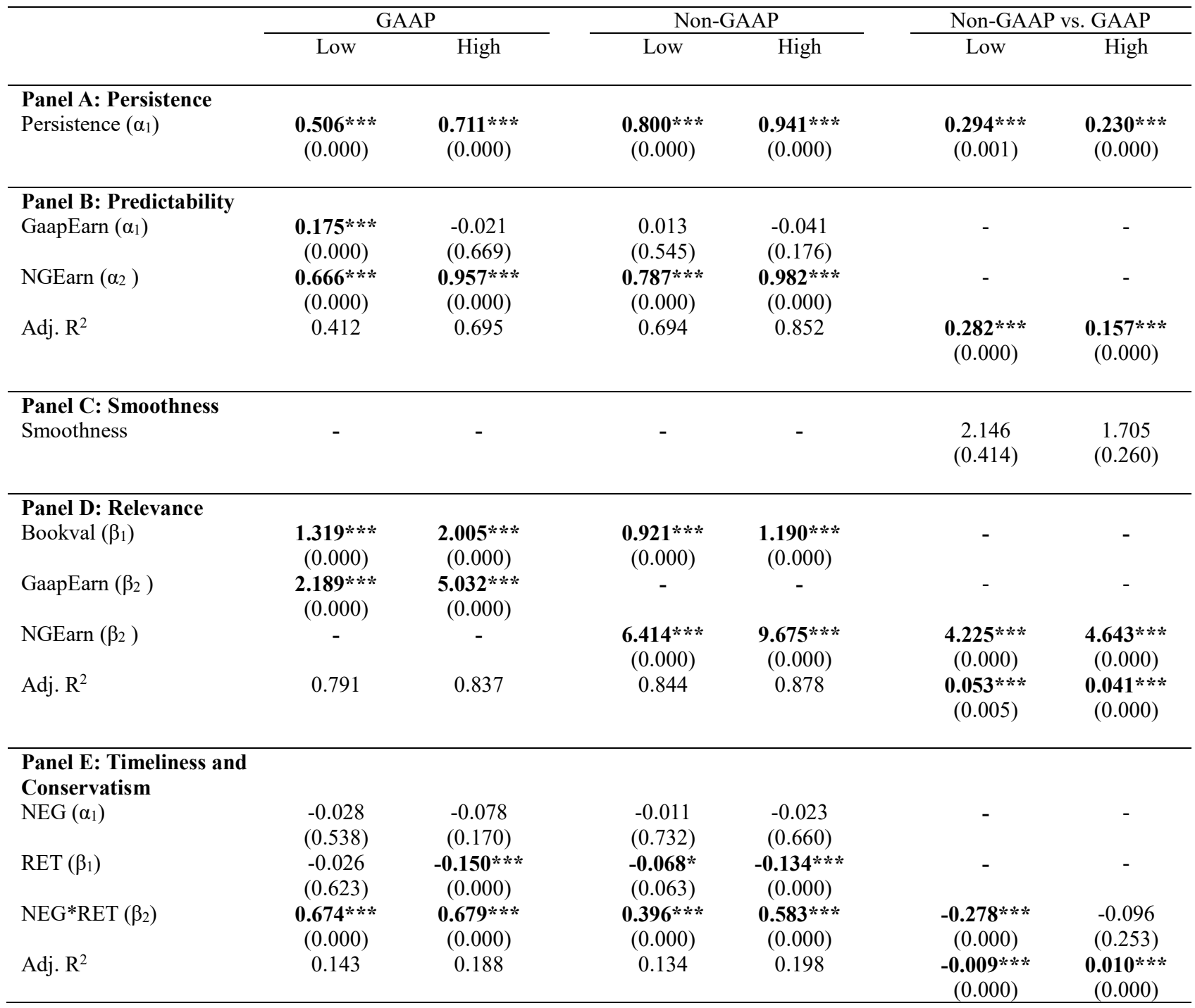

For earnings persistence, we estimate the following regression:

$$
\operatorname{Earn}_{t+1}=\alpha_{0}+\alpha_{1} \operatorname{Earn}_{t}+v_{t+1} \quad \text { (1) }
$$

where Earn is GAAP earnings per share (GaapEarn), calculated as the disclosed GAAP earnings together with non-GAAP earnings collected from a firm's earnings press release divided by the number of total shares outstanding for firm i at time $t$, or non-GAAP earnings per share (NGEarn), calculated as the non-GAAP earnings metric collected from earnings press release divided by the number of total shares outstanding for firm i at time $t$; $v$ is the error term. For earnings predictability, we estimate the regression models as follows:

We calculate earnings smoothness as:

$$
\operatorname{Earn}_{i, t+1}=\alpha_{0, i}+\alpha_{1, i} \operatorname{GaapEarn}_{i, t}+\alpha_{2, i} \operatorname{NGEarn}_{i, t}+\varepsilon_{i, t}
$$

Earnings smoothness $s_{i, t}=\sigma\left(\right.$ GaapEarn $\left._{i, t}\right) / \sigma(N G$ Earni, $t) \quad(3)$

where Earnings smoothness E $_{i, t}$ is the ratio of firm i's standard deviation of GAAP earnings over the most recent three years divided by beginning total assets, to its standard deviation of non-GAAP earnings divided by beginning total assets. Value relevance is estimated using the following models:

$$
\text { Price }_{i, t}=\alpha_{0, i}+\beta_{1} \text { Bookval }_{i, t}+\beta_{2} \text { Earn }_{i, t}+\varepsilon_{i, t} \quad \text { (4) }
$$

where Price $_{i, t}$ is the fiscal year-end closing price, adjusted for stock splits and stock dividends for firm i at time $\mathrm{t}$; Bookval ${ }_{i, t}$ is common equity per share for firm $\mathrm{i}$ at time $\mathrm{t}$; and $\varepsilon_{i, t}$ is the error term. For timeliness and conservatism, we use the following models:

$$
E A R N_{j, t}=\alpha_{0, j}+\alpha_{1, j} N E G_{j, t}+\beta_{l, j} R E T_{j, t}++\beta_{2, j} N E G_{j, t} * R E T_{j, t}+\varsigma_{j, t}(5)
$$

where $N E G_{j, t}$ equal to 1 if $R E T$ is negative; $R E T_{j, t}$ is firm j's 12-month return ending three months after the end of fiscal year $\mathrm{t}$ 


\section{Table 7: Pooled regressions comparing the quality of GAAP vs. Non-GAAP earnings: High vs. Low disclosure propensity of non-GAAP earnings}

This table reports the results of pooled time-series and cross-sectional regressions that examine the quality of GAAP earnings and non-GAAP earnings. Industry (based on the 25 SIRCA industry classification) and year fixed effects are included for all earnings quality measures. Definitions of all variables can be found in the Appendix. *** $(* *, *)$ indicates significant at the $1 \%(5 \%, 10 \%)$ level for two-tailed test.

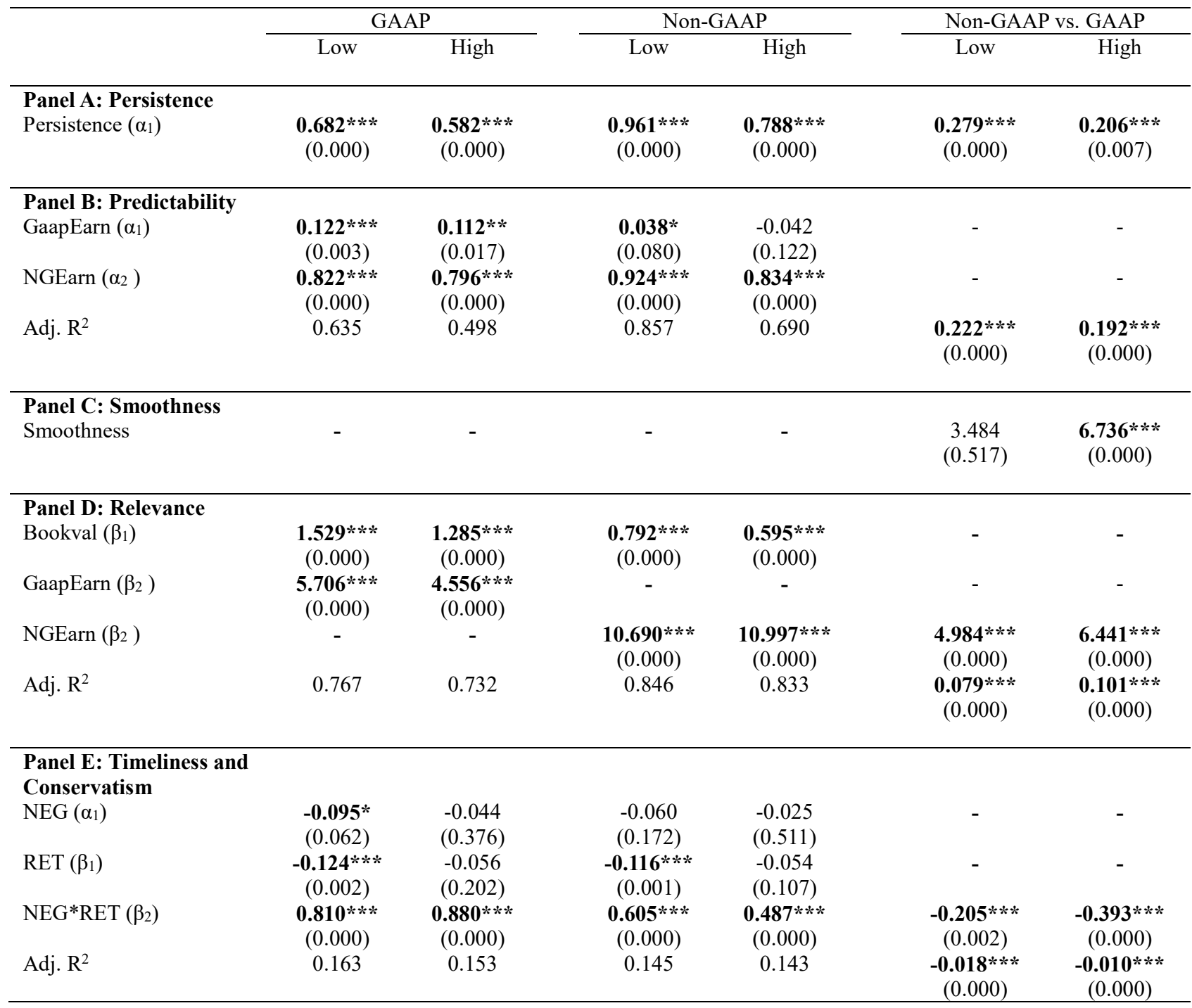

For earnings persistence, we estimate the following regression:

$$
\operatorname{Earn}_{t+1}=\alpha_{0}+\alpha_{1} \operatorname{Earn}_{t}+v_{t+1} \quad(1)
$$

where Earn is GAAP earnings per share (GaapEarn), calculated as the disclosed GAAP earnings together with non-GAAP earnings collected from a firm's earnings press release divided by the number of total shares outstanding for firm i at time $t$, or non-GAAP earnings per share (NGEarn), calculated as the non-GAAP earnings metric collected from earnings press release divided by the number of total shares outstanding for firm i at time $t$; $v$ is the error term. For earnings predictability, we estimate the regression models as follows:

We calculate earnings smoothness as

$$
\operatorname{Earn}_{i, t+1}=\alpha_{0, i}+\alpha_{1, i} \operatorname{GaapEarn}_{i, t}+\alpha_{2, i} \operatorname{NGEarn}_{i, t}+\varepsilon_{i, t}
$$

Earnings smoothness $s_{i, t}=\sigma\left(\right.$ GaapEarn $\left._{i, t}\right) / \sigma(N G$ Earni, $t) \quad(3)$

where Earnings smoothness E $_{i, t}$ is the ratio of firm i's standard deviation of GAAP earnings over the most recent three years divided by beginning total assets, to its standard deviation of non-GAAP earnings divided by beginning total assets. Value relevance is estimated using the following models:

$$
\text { Price }_{i, t}=\alpha_{0, i}+\beta_{1} \text { Bookval }_{i, t}+\beta_{2} \text { Earn }_{i, t}+\varepsilon_{i, t} \quad \text { (4) }
$$

where Price $_{i, t}$ is the fiscal year-end closing price, adjusted for stock splits and stock dividends for firm i at time $\mathrm{t}$; Bookval ${ }_{i, t}$ is common equity per share for firm $\mathrm{i}$ at time $\mathrm{t}$; and $\varepsilon_{i, t}$ is the error term. For timeliness and conservatism, we use the following models:

$$
E A R N_{j, t}=\alpha_{0, j}+\alpha_{1, j} N E G_{j, t}+\beta_{l, j} R E T_{j, t}++\beta_{2, j} N E G_{j, t} * R E T_{j, t}+\varsigma_{j, t}(5)
$$

where $N E G_{j, t}$ equal to 1 if $R E T$ is negative; $R E T_{j, t}$ is firm j's 12-month return ending three months after the end of fiscal year $\mathrm{t}$. 


\section{Table 8: Pooled regressions comparing the quality of GAAP vs. Non-GAAP earnings: Profitable vs. loss firms}

This table reports the results of pooled time-series and cross-sectional regressions that examine the quality of GAAP earnings and non-GAAP earnings. Industry (based on the 25 SIRCA industry classification) and year fixed effects are included for all earnings quality measures. Definitions of all variables can be found in the Appendix. *** $(* *, *)$ indicates significant at the $1 \%(5 \%, 10 \%)$ level for two-tailed test.

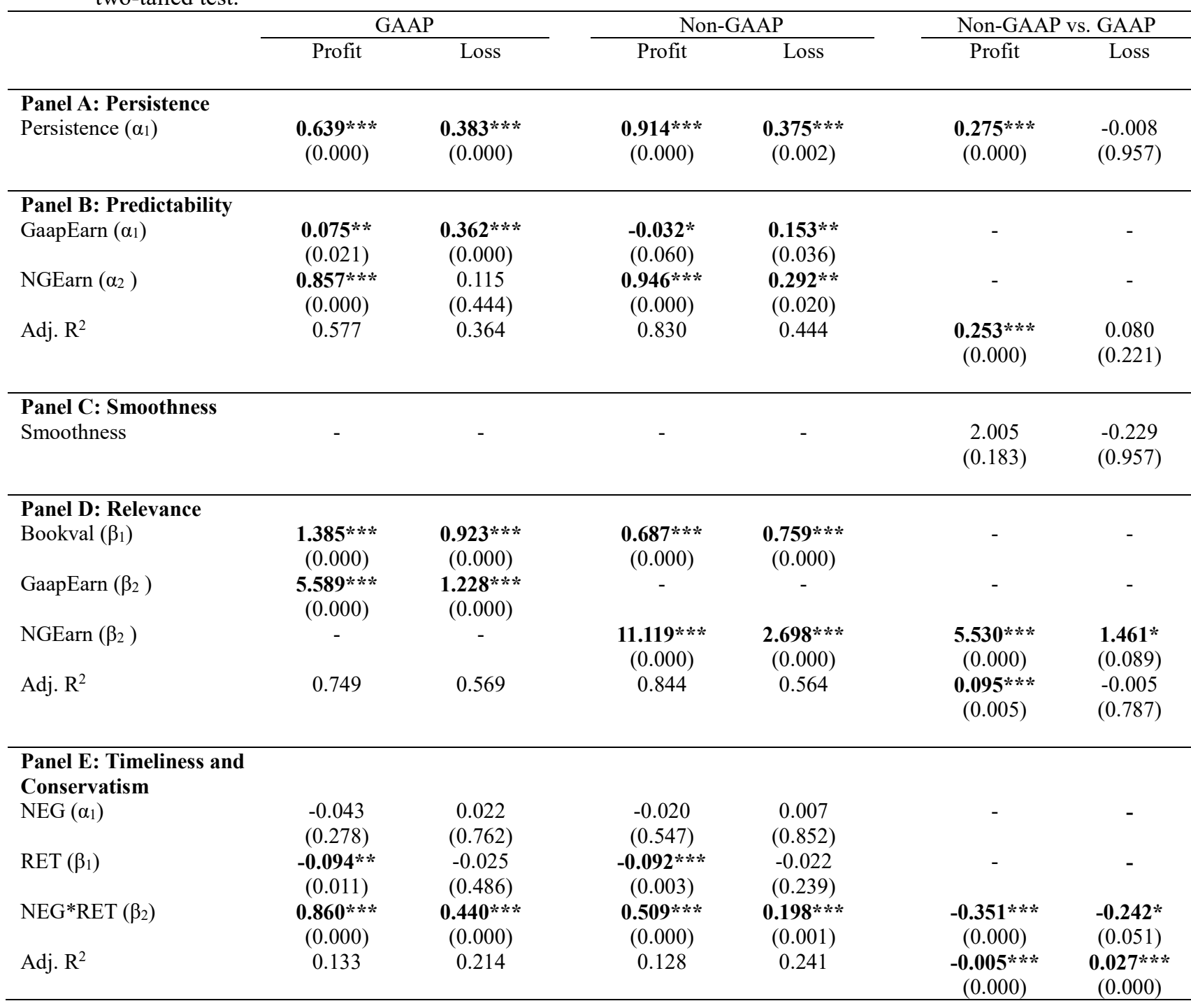

For earnings persistence, we estimate the following regression:

$$
\operatorname{Earn}_{t+1}=\alpha_{0}+\alpha_{1} \operatorname{Earn}_{t}+v_{t+1} \quad \text { (1) }
$$

where Earn is GAAP earnings per share (GaapEarn), calculated as the disclosed GAAP earnings together with non-GAAP earnings collected from a firm's earnings press release divided by the number of total shares outstanding for firm i at time t, or non-GAAP earnings per share (NGEarn), calculated as the non-GAAP earnings metric collected from earnings press release divided by the number of total shares outstanding for firm $i$ at time $t$; $v$ is the error term. For earnings predictability, we estimate the regression models as follows:

We calculate earnings smoothness as:

$$
\operatorname{Earn}_{i, t+1}=\alpha_{0, i}+\alpha_{1, i} \operatorname{GaapEarn}_{i, t}+\alpha_{2, i} \operatorname{NGEarn}_{i, t}+\varepsilon_{i, t}
$$

Earnings smoothness $s_{i, t}=\sigma\left(\right.$ GaapEarn $\left._{i, t}\right) / \sigma($ NGEarni, $)$

(3)

where Earnings smoothness $s_{i, t}$ is the ratio of firm i's standard deviation of GAAP earnings over the most recent three years divided by beginning total assets, to its standard deviation of non-GAAP earnings divided by beginning total assets. Value relevance is estimated using the following models:

$$
\text { Price }_{i, t}=\alpha_{0, i}+\beta_{1} \text { Bookval }_{i, t}+\beta_{2} \text { Earn }_{i, t}+\varepsilon_{i, t} \quad \text { (4) }
$$

where Price $_{i, t}$ is the fiscal year-end closing price, adjusted for stock splits and stock dividends for firm i at time t; Bookval $l_{i, t}$ is common equity per share for firm $\mathrm{i}$ at time $\mathrm{t}$; and $\varepsilon_{i, t}$ is the error term. With respect to timeliness and conservatism, we use the following models:

$$
E A R N_{j, t}=\alpha_{0, j}+\alpha_{1, j} N E G_{j, t}+\beta_{1, j} R E T_{j, t}++\beta_{2, j} N E G_{j, t} * R E T_{j, t}+\varsigma_{j, t}(5)
$$

where $N E G_{j, t}$ equal to 1 if $R E T$ is negative; $R E T_{j, t}$ is firm j's 12 -month return ending three months after the end of fiscal year $\mathrm{t}$ 


\section{Table 9: Pooled regressions comparing the quality of GAAP vs. Non-GAAP earnings: High versus low board independence}

This table reports the results of pooled time-series and cross-sectional regressions that examine the quality of GAAP earnings and non-GAAP earnings. Industry (based on the 25 SIRCA industry classification) and year fixed effects are included for all earnings quality measures. Definitions of all variables can be found in the Appendix. *** $(* *, *)$ indicates significant at the $1 \%(5 \%, 10 \%)$ level for two-tailed test.

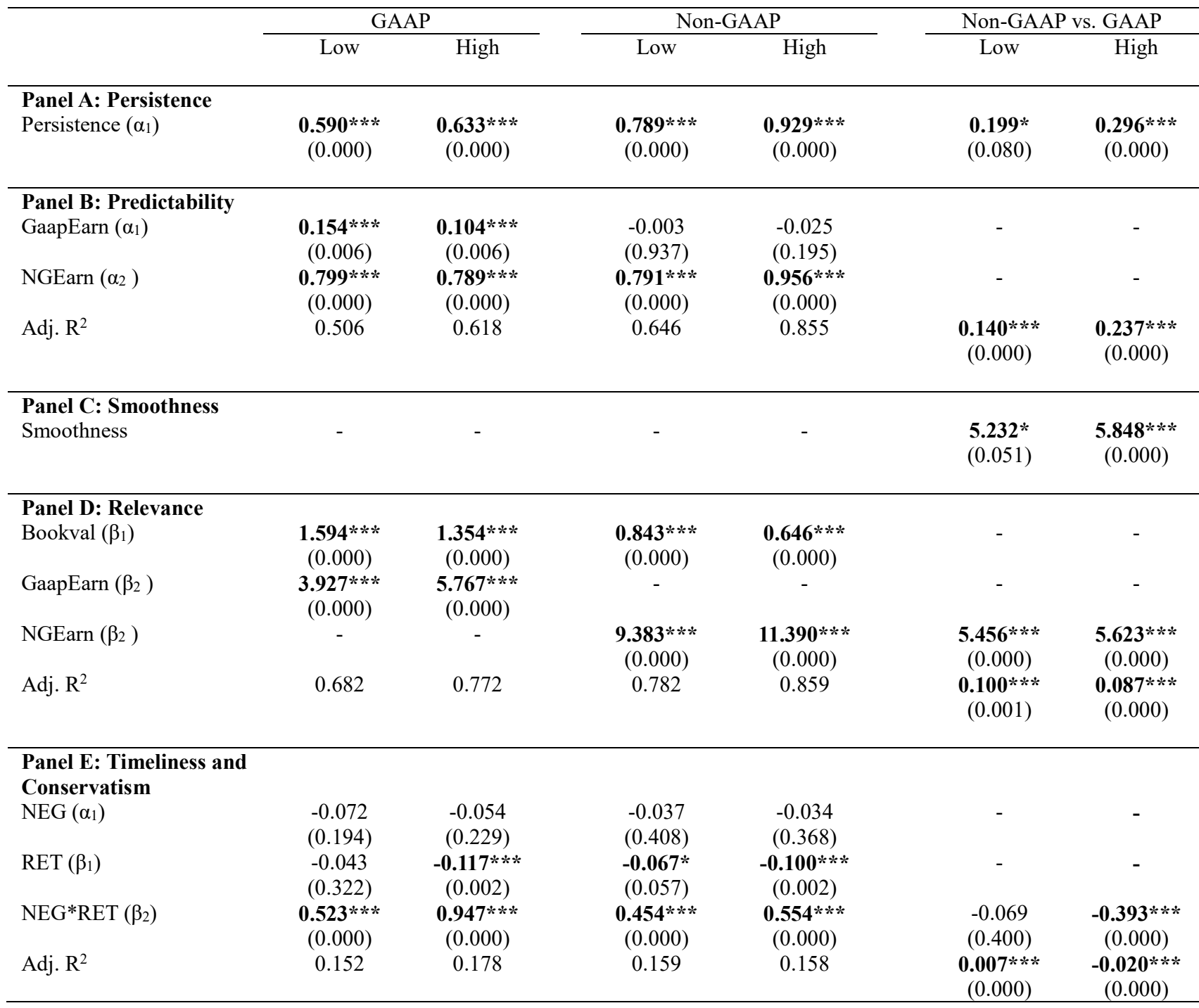

For earnings persistence, we estimate the following regression:

$$
\operatorname{Earn}_{t+1}=\alpha_{0}+\alpha_{1} \operatorname{Earn}_{t}+v_{t+1} \quad(1)
$$

where Earn is GAAP earnings per share (GaapEarn), calculated as the disclosed GAAP earnings together with non-GAAP earnings collected from a firm's earnings press release divided by the number of total shares outstanding for firm i at time $t$, or non-GAAP earnings per share (NGEarn), calculated as the non-GAAP earnings metric collected from earnings press release divided by the number of total shares outstanding for firm i at time $t$; $v$ is the error term. For earnings predictability, we estimate the regression models as follows:

We calculate earnings smoothness as:

$$
\operatorname{Earn}_{i, t+1}=\alpha_{0, i}+\alpha_{1, i} \operatorname{GaapEarn}_{i, t}+\alpha_{2, i} \operatorname{NGEarn}_{i, t}+\varepsilon_{i, t}
$$

Earnings smoothness $s_{i, t}=\sigma\left(\right.$ GaapEarn $\left._{i, t}\right) / \sigma(N G$ Earni, $t) \quad(3)$

where Earnings smoothness E $_{i, t}$ is the ratio of firm i's standard deviation of GAAP earnings over the most recent three years divided by beginning total assets, to its standard deviation of non-GAAP earnings divided by beginning total assets. Value relevance is estimated using the following models:

$$
\text { Price }_{i, t}=\alpha_{0, i}+\beta_{1} \text { Bookval }_{i, t}+\beta_{2} \text { Earn }_{i, t}+\varepsilon_{i, t} \quad \text { (4) }
$$

where Price $_{i, t}$ is the fiscal year-end closing price, adjusted for stock splits and stock dividends for firm $\mathrm{i}$ at time $\mathrm{t}$; Bookval $\mathrm{i}_{i, t}$ is common equity per share for firm $\mathrm{i}$ at time $\mathrm{t}$; and $\varepsilon_{i, t}$ is the error term. With respect to timeliness and conservatism, we use the following models:

$$
E A R N_{j, t}=\alpha_{0, j}+\alpha_{l, j} N E G_{j, t}+\beta_{l, j} R E T_{j, t}++\beta_{2, j} N E G_{j, t} * R E T_{j, t}+\varsigma_{j, t}(5)
$$

where $N E G_{j, t}$ equal to 1 if $R E T$ is negative; $R E T_{j, t}$ is firm j's 12-month return ending three months after the end of fiscal year $\mathrm{t}$. 